IZA DP No. 4627

Minimum-Income Benefits in OECD Countries:

Policy Design, Effectiveness and Challenges

Herwig Immervoll

December 2009 


\title{
Minimum-Income Benefits in OECD Countries: Policy Design, Effectiveness and Challenges
}

\author{
Herwig Immervoll \\ OECD, ISER, University of Essex, \\ European Centre Vienna, NATSEM and IZA
}

Discussion Paper No. 4627

December 2009

\author{
IZA \\ P.O. Box 7240 \\ 53072 Bonn \\ Germany \\ Phone: +49-228-3894-0 \\ Fax: +49-228-3894-180 \\ E-mail: iza@iza.org
}

\begin{abstract}
Any opinions expressed here are those of the author(s) and not those of IZA. Research published in this series may include views on policy, but the institute itself takes no institutional policy positions.

The Institute for the Study of Labor (IZA) in Bonn is a local and virtual international research center and a place of communication between science, politics and business. IZA is an independent nonprofit organization supported by Deutsche Post Foundation. The center is associated with the University of Bonn and offers a stimulating research environment through its international network, workshops and conferences, data service, project support, research visits and doctoral program. IZA engages in (i) original and internationally competitive research in all fields of labor economics, (ii) development of policy concepts, and (iii) dissemination of research results and concepts to the interested public.
\end{abstract}

IZA Discussion Papers often represent preliminary work and are circulated to encourage discussion. Citation of such a paper should account for its provisional character. A revised version may be available directly from the author. 
IZA Discussion Paper No. 4627

December 2009

\title{
ABSTRACT
}

\section{Minimum-Income Benefits in OECD Countries: Policy Design, Effectiveness and Challenges}

\begin{abstract}
Almost all OECD countries operate comprehensive minimum-income programmes for working-age individuals, either as last-resort safety nets alongside primary income replacement benefits, or as the principal instrument for delivering social protection. Such safety-net benefits aim primarily at providing an acceptable standard of living for families unable to earn sufficient incomes from other sources. This paper provides an overview of social assistance and other minimum-income programmes in OECD countries, summarises their main features, and highlights a number of current policy challenges.
\end{abstract}

JEL Classification: $\quad$ I38, H53, D31, H31

Keywords: $\quad$ social assistance, negative income tax, welfare to work, poverty

Corresponding author:

Herwig Immervoll

OECD

2 , rue André-Pascal

75775 Paris Cedex 16

France

E-mail: herwig.immervoll@oecd.org 
IZA Discussion Paper No. 4627

December 2009

\section{NON-TECHNICAL SUMMARY}

The current economic downturn is putting pressures on governments to strengthen income support measures. While buoyant labour markets in many OECD countries have helped to restrain recipiency numbers since the mid-late nineties, the current rapid decline in economic activity can be expected to be a powerful driver of the demand for minimum safety-nets.

In addition to the expected lengthening of average unemployment spells, and the resulting rising number of people running out of unemployment benefit entitlements, those with temporary jobs or other forms of non-standard employment are often not entitled to unemployment benefits in the first place. For these individuals, employment durations are shorter, transitions into and out of work more frequent and coverage by social insurance benefits can be less universal as a result. They are also typically more easily shed from the workforce. With increasing shares of non-standard workers in a number of OECD countries, this may cause social assistance benefit rolls to react more strongly to labour-market conditions (i.e., become more counter-cyclical) than was the case in the past. In the medium term, some of these challenges point to the need for a debate on the relative roles of insurance and assistance benefits. For instance, should coverage of insurance benefits be extended to non-standard workers or should lower-tier assistance benefits be strengthened?

More urgently, there is a need to consider how an activation and reintegration focus can be maintained when labour demand is weak and competition for existing job vacancies intense (OECD, 2009b, c). Where minimum-income programmes are lower-tier benefits, recipients tend to face significantly less promising employment prospects in a slack labour market than recipients of unemployment benefits with more recent work experience. Yet, the group of minimum-income beneficiaries is very heterogeneous in most countries including, for instance, those with recent but intermittent employment records and other recent job losers who do not qualify for insurance benefits. Increasing numbers of benefit recipients are likely to test the capacity of welfare agencies and public employment services to administer highquality activation programmes and job-search assistance to everybody. This will further add to the challenge of targeting activation and support measures in a way that minimises benefit spells for the most employable, while preventing less employable clients from becoming permanently benefit-dependent.

The most immediate priority, however, is to prevent support seekers from going without effective minimum safety-nets at a time when they are most needed. Preventing steep increases in the extent and severity of poverty is likely to present a particularly difficult shortterm challenge for those countries that are not currently operating broad minimum-income programmes. In addition, existing social assistance programmes are likely to see new clients added at much faster rates as unemployment durations lengthen. They will only be able to continue meeting their objectives of poverty alleviation and activation if they are equipped with the financial and operational capacity to deal with the inflow of new claimants and an increasing stock of recipients. 


\section{TABLE OF CONTENTS}

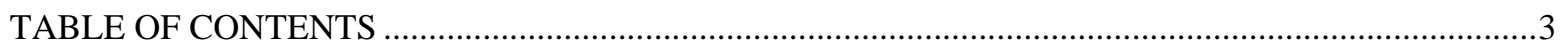

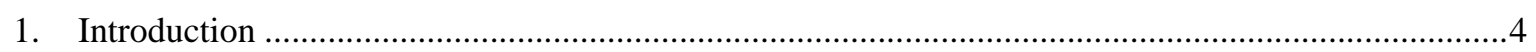

2. A typology of minimum-income benefits: scope and links with other transfer programmes................5

3. Generosity: Benefit levels and related support measures ...............................................................11

3.1 Benefit levels in relation to median incomes and relative poverty thresholds ...........................11

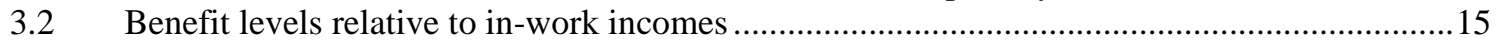

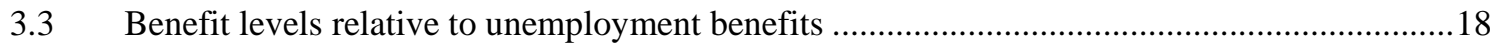

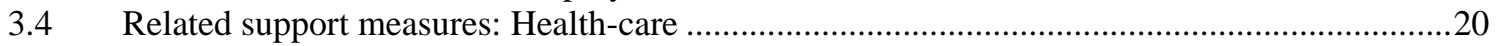

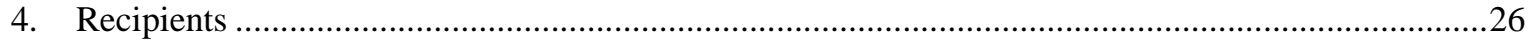

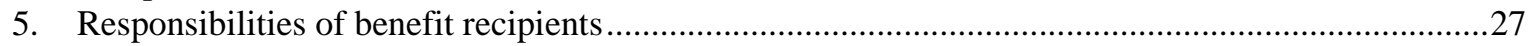

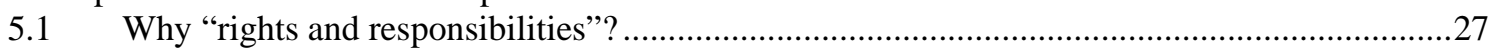

5.2 Targeting: The right mix of rights and responsibilities, for the right people, at the right time .29

$5.3 \quad$ An illustration of benefit recipients' obligations ...........................................................................

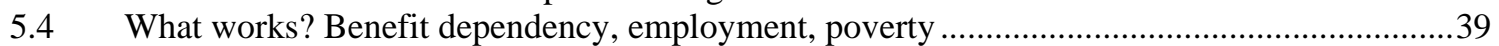

6. Institutional context, programme implementation and service delivery .........................................43

7. Concluding comments: current and future challenges ........................................................................46

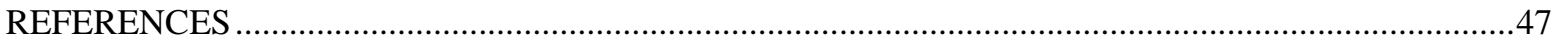

\section{Tables}

Table 1. Public social expenditure in OECD countries: levels and composition, 2005 .....................6

Table 2. Main cash benefits for able-bodied working-age individuals and their families, 2007 ...........8

Table 3. Benefit phase-outs points and benefit withdrawal rates ......................................................14

Table 4. Minimum-income benefit levels relative to unemployment benefits ...................................19

Table 5. Health-related support for benefit recipients and low-income groups ...................................22

Table 6. Behavioural requirements and benefit sanctions ................................................................33

Table 7. Work tests for lone parents, selected countries, around 2006 ..............................................38

\section{Figures}

Figure 1. A typology: Rank and scope of minimum-income benefits ................................................11

Figure 2. Income levels provided by cash minimum-income benefits ................................................12

Figure 3. Net incomes of benefit recipients and full-time minimum-wage earners..............................16

Figure 4. Number of households receiving minimum-income benefits relative to income-poor

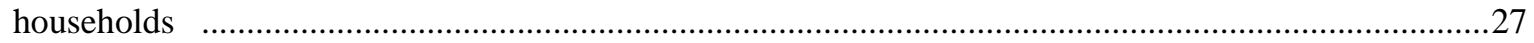




\section{MINIMUM-INCOME BENEFITS IN OECD COUNTRIES: POLICY DESIGN, EFFECTIVENESS AND CHALLENGES ${ }^{1}$}

\section{Introduction}

Almost all OECD countries operate comprehensive minimum-income programmes for working-age individuals and their families, either as last-resort safety nets alongside primary income replacement benefits, or as the principal instrument for delivering social protection. These safety-net benefits aim at providing an acceptable standard of living for families unable to earn sufficient incomes from other sources. As anti-poverty measures, they reduce income disparities at the bottom of the income spectrum and, as such, represent important building blocks of redistribution policies. Equally important, they act as safety nets for individuals experiencing low-income spells and, hence, help to smooth income levels over time.

This paper provides a broad overview of contemporary minimum-income transfers in OECD countries. $^{2}$ In the policy debate, as well as in economic models, such transfers are occasionally characterised as simple income floors. Yet, while benefit levels are important, the extent to which they shape distributional outcomes depends on a multitude of other factors. To appreciate country differences in the role of minimum-income benefits, and in the situation of benefit recipients, it is necessary to look at a range of policy parameters in combination.

One important factor is the way in which benefits of last resort are embedded in the wider social policy framework. For example, their significance as a redistribution instrument evidently differs between countries where they complement other benefits that provide powerful first-tier safety nets (as in much of continental Europe) and those where they represent the main benefit (as in Australia, New Zealand). Consequently, reforms of higher-tier benefits will often have implications for minimum-income programmes in terms of spending levels, the number and characteristics of benefit recipients, as well as optimal strategies for supporting them.

Since the 1990's, social policy debates in OECD countries have increasingly emphasised the need for "active" and "activating" support. Although the balance varies very much between countries and policy areas, such support includes assistance for those making efforts towards regaining self-sufficiency, allied to the possibility of benefit sanctions if a client's own efforts are considered inadequate. Attempts to rebalance policies from passive income assistance towards strengthening self-sufficiency have, at least in principle, been a central element of reform initiatives across a broad range of social policy areas. The successes of such efforts have nevertheless been uneven. While those who are, in some sense, closest to the labour market are in a good position to benefit from work-oriented support, achieving lasting labour market integration and adequate incomes has proved much more difficult for other social policy clients, including recipients of social assistance and other benefits of last resort.

1. I wish to thank delegates to the OECD Working Party on Social Policy for providing responses to policy questionnaires. I also thank Jonathan Bradshaw for helpful comments and Sebastian Königs for outstanding research assistance. Any remaining errors and views expressed in this paper are my responsibility. In particular, the paper does not represent the views of the OECD or the Governments of OECD member countries.

2. Much more comprehensive earlier reviews of social assistance policies in different countries include Eardley et al. (1996), OECD (1998a; 1998b; 1999) as well as Adema et al. (2003). In-depth information on, and analyses of, policies in individual countries is available in the OECD's Benefits and Wages series which includes information on policy institutions and parameters, as well as indicators on income adequacy and work incentives (www.oecd.org/els/social/workincentives). Activation policies are the subject of ongoing OECD policy reviews and other analytical work (see www.oecd.org/els/employment/almp). 
The question of how to maintain active social policies in a context of weak labour markets, as experienced during the current economic crisis, brings renewed momentum to this debate.

The paper starts out by proposing a simple typology for situating different types of minimum-income benefits as elements of the overall redistribution system. Section 3 summarises the generosity of benefit payments and summarises the structure of health-care-related support measures that complement cash benefit payments. Section 4 describes the limited available comparative data on the number of benefit claimants and considers to what extent they matter when assessing the relevance of social assistance measures as safety nets. Section 5 provides a condensed overview of the "mutual obligations" debate discussing, in turn, the rationale of back-to-work and other activation measures, the different approaches used in different countries, and the main results from the evaluation literature. Section 6 illustrates some institutional and implementation aspects of administering benefit payments and re-integration services. The last section concludes by highlighting some challenges for minimum-income programmes posed by the current economic downturn.

\section{A typology of minimum-income benefits: scope and links with other transfer programmes}

Benefits of last resort mean different things in different countries and for different population groups. For the purpose of this paper, they are defined as cash or in-kind transfers that aim at preventing extreme hardship and employ a low-income criterion as the central entitlement condition. Benefits of last resort therefore include social assistance benefits as well as other means-tested assistance payments that are typically received by families with no other income sources (although, as discussed below, the same benefits can to some extent also top up the incomes of low-paid workers and other low-income groups). Examples are means-tested lone-parent benefits, as well as unemployment assistance benefits that are not conditional on work or contribution histories (as in Australia, Finland, Germany, Ireland, New Zealand, UK). The terminology used to describe benefits of last resort varies across countries. In what follows, 'social assistance' is used to refer to minimum-income benefits that are generally available and, thus, not targeted to specific population groups. 'Minimum-income benefit' is a broader concept that includes social assistance but also other, more targeted, programmes with a similar function (e.g., means-tested loneparent benefits). I use the terms 'minimum-income benefit', 'minimum safety-net benefits', 'welfare benefits' and 'last-resort benefits' synonymously. To focus the discussion, this paper is limited to benefits targeted at able-bodied working-age individuals and their families. ${ }^{3}$

In most areas of social spending, overall expenditure data are a good starting point for appreciating country variations in terms of the significance of policies that address different contingencies. The variation of spending patterns across countries is illustrated in Table 1 using recent social expenditure data compiled by the OECD. The columns on the right show breakdowns of total public spending across nine social policy domains, while the first three columns report total spending levels as well as spending on cash benefits and on income-tested programmes. It is apparent that targeting low-income groups is a central design feature of cash transfer programmes in several OECD countries including the UK, Ireland,

3. Depending on the structure of support available for individuals with health problems as well as (early) retirees, these groups may fall into the scope of broadly-defined minimum-income programmes. At the same time, very large numbers of recipients of disability or early-retirement benefits in several OECD countries illustrate that these benefits can end up being used for contingencies for which they were not designed (such as long-term unemployment). The particular issues that are pertinent for these two groups are outside the scope of this paper. Issues related specifically to benefit claimants with disabilities or other health-related problems are discussed in the OECD series Sickness, Disability and Work (see www.oecd.org/els/disability). Pension policies, including means-tested, basic and minimum pensions, are discussed in Pensions at a Glance (www.oecd.org/els/social/pag). The latest issue in this series contains a chapter on poverty among old-age individuals (OECD, 2009a). Finally, employment barriers for older workers have been the subject of in-depth country reviews (www.oecd.org/olderworkersforum). 
New Zealand, Canada and, most notably, Australia. In countries with extensive social insurance benefits, the budgetary relevance of means-tested transfers is correspondingly lower.

Table 1. Public social expenditure in OECD countries: levels and composition, $2005^{(1)(2)}$

\begin{tabular}{|c|c|c|c|c|c|c|c|c|c|c|c|c|}
\hline \multirow[b]{3}{*}{ Australia } & Total & Cash & $\begin{array}{l}\text { Income- } \\
\text { tested }\end{array}$ & Old age & Survivors & $\begin{array}{l}\text { Incapa } \\
\text { city } \\
\text { related }\end{array}$ & Health & Family & $\begin{array}{c}\text { Active } \\
\text { labour } \\
\text { market } \\
\text { prog. }\end{array}$ & $\begin{array}{l}\text { Unemploy } \\
\text { ment }\end{array}$ & Housing & $\begin{array}{l}\text { Other } \\
\text { social } \\
\text { policy } \\
\text { areas }\end{array}$ \\
\hline & \multicolumn{3}{|c|}{ in $\%$ of GDP } & \multicolumn{9}{|c|}{ in $\%$ of total spending } \\
\hline & 17.1 & 8.1 & 6.3 & 26.0 & 1.2 & 14.2 & 34.3 & 16.5 & 2.2 & 3.2 & 1.5 & 0.8 \\
\hline Austria & 27.2 & 18.4 & 1.1 & 46.5 & 1.3 & 8.8 & 25.1 & 10.4 & 2.3 & 4.2 & 0.4 & 1.1 \\
\hline Belgium & 26.4 & 16.2 & 0.9 & 27.2 & 7.7 & 8.9 & 27.8 & 9.9 & 4.1 & 12.6 & 0.3 & 1.7 \\
\hline Canada & 16.5 & 6.8 & 3.3 & 22.6 & 2.4 & 5.6 & 41.5 & 6.4 & 1.8 & 3.8 & 2.7 & 13.3 \\
\hline Czech Republic & 19.5 & 11.4 & 1.6 & 38.3 & 0.9 & 12.4 & 32.4 & 8.9 & 1.3 & 3.2 & 0.4 & 2.3 \\
\hline Denmark & 27.1 & 13.6 & 1.0 & 26.8 & 0.0 & 15.9 & 21.6 & 12.5 & 6.5 & 10.4 & 2.6 & 3.7 \\
\hline Finland & 26.1 & 15.3 & 2.6 & 32.6 & 3.4 & 14.7 & 23.8 & 11.4 & 3.4 & 7.7 & 1.1 & 1.9 \\
\hline France & 29.2 & 17.5 & 1.9 & 37.4 & 6.1 & 6.3 & 26.9 & 10.3 & 3.1 & 5.9 & 2.8 & 1.2 \\
\hline Germany & 26.7 & 15.9 & 1.5 & 42.0 & 1.4 & 7.0 & 28.7 & 8.1 & 3.6 & 6.2 & 2.3 & 0.8 \\
\hline Greece & 20.5 & 13.4 & 1.3 & 52.5 & 3.9 & 4.4 & 27.4 & 5.3 & 0.3 & 1.9 & 2.5 & 1.8 \\
\hline Hungary & 22.5 & 13.6 & 0.6 & 39.2 & 1.2 & 12.5 & 26.6 & 13.8 & 1.3 & 2.5 & 2.3 & 0.7 \\
\hline Iceland & 16.9 & 5.7 & 1.0 & 22.6 & 0.2 & 15.9 & 37.4 & 17.6 & 0.5 & 1.8 & 1.2 & 2.9 \\
\hline Ireland & 16.7 & 8.4 & 2.6 & 17.3 & 5.0 & 9.7 & 38.8 & 14.9 & 3.8 & 5.4 & 3.1 & 2.1 \\
\hline Italy & 25.0 & 16.7 & 0.7 & 46.4 & 9.9 & 6.8 & 27.3 & 5.2 & 2.3 & 2.0 & 0.1 & 0.1 \\
\hline Japan & 18.6 & 10.2 & 0.5 & 46.4 & 6.9 & 3.8 & 34.0 & 4.4 & 1.4 & 1.8 & & 1.4 \\
\hline Korea & 6.9 & 2.9 & 0.7 & 22.3 & 3.6 & 8.2 & 46.2 & 4.0 & 1.9 & 3.1 & & 10.7 \\
\hline Luxembourg & 23.2 & 13.9 & 0.5 & 22.6 & 8.7 & 14.1 & 30.1 & 15.5 & 2.2 & 4.2 & 0.7 & 1.9 \\
\hline Mexico & 7.4 & 2.5 & 0.5 & 13.8 & 4.0 & 0.9 & 39.2 & 13.5 & 0.3 & & 14.9 & 13.4 \\
\hline Netherlands & 20.9 & 11.1 & 1.1 & 26.5 & 1.4 & 17.3 & 28.5 & 7.9 & 6.4 & 7.3 & 1.6 & 3.0 \\
\hline New Zealand & 18.5 & 9.7 & 3.4 & 22.8 & 0.8 & 15.5 & 37.2 & 14.2 & 2.1 & 2.4 & 4.3 & 0.8 \\
\hline Norway & 21.6 & 10.9 & 1.1 & 29.2 & 1.3 & 20.3 & 26.7 & 13.1 & 3.4 & 2.5 & 0.7 & 2.8 \\
\hline Poland & 21.0 & 15.7 & 1.1 & 49.7 & 4.8 & 12.8 & 20.5 & 5.4 & 2.0 & 2.6 & 0.6 & 1.7 \\
\hline Portugal & 22.9 & 13.9 & 1.7 & 36.3 & 6.6 & 10.5 & 31.0 & 6.5 & 2.9 & 4.7 & 0.0 & 1.4 \\
\hline Slovak Republic & 16.6 & 10.2 & 0.6 & 37.3 & 1.3 & 10.1 & 31.9 & 12.8 & 2.1 & 1.6 & 0.0 & 3.0 \\
\hline Spain & 21.2 & 13.1 & 1.6 & 37.1 & 2.6 & 11.7 & 27.5 & 5.4 & 3.6 & 10.4 & 0.8 & 0.9 \\
\hline Sweden & 29.4 & 14.5 & 0.6 & 32.6 & 2.1 & 19.0 & 23.0 & 10.9 & 4.4 & 4.1 & 1.8 & 2.0 \\
\hline Switzerland & 20.3 & 11.8 & 1.1 & 32.7 & 1.8 & 16.3 & 29.9 & 6.6 & 3.7 & 4.6 & 0.8 & 3.7 \\
\hline Turkey & 13.7 & 8.1 & 0.5 & 46.7 & 11.5 & 1.5 & 39.6 & 0.2 & 0.0 & 0.4 & & \\
\hline United Kingdom & 21.3 & 10.3 & 2.7 & 28.6 & 0.9 & 11.2 & 32.9 & 15.0 & 2.5 & 1.2 & 6.8 & 0.9 \\
\hline United States & 15.9 & 8.0 & 1.2 & 33.3 & 4.8 & 8.1 & 43.7 & 3.9 & 0.8 & 1.9 & & 3.6 \\
\hline OECD - Total & 20.6 & 11.6 & 1.5 & 33.2 & 3.6 & 10.8 & 31.4 & 9.7 & 2.5 & 4.3 & 2.2 & 2.9 \\
\hline
\end{tabular}

1. Data are before tax and account neither for the tax treatment of social benefits nor for tax expenditure (such as tax deductions for children), although tax credits that are paid in cash are included. The OECD also calculates net spending data which address these issues (see link in the sources).

2. Blank entries indicate that data are not available. Data for Portugal are for 2003. The following income-tested spending items are included in the 'income-tested' category: spending on "other contingencies - other social policy areas", income-tested spending on the unemployed (e.g. unemployment assistance payments for Germany), income-tested support payments to elderly and disabled (e.g. Belgium, and the UK), other income tested payments (family cash transfers) but do not include specific housing subsidies, spending on Active Labour Market Policies, or income-tested medical support.

Source: extraction from the preliminary 2005 wave of the OECD Social Expenditure Database (www.oecd.org/els/social/expenditure).

However, for a number of reasons, these numbers are likely to portray a distorted picture of spending on minimum-income benefits as defined above. First, programme-level spending data is not always available and the decision whether or not to count broader benefit categories as means-tested can therefore be ambiguous. For the same reason, it is not straightforward to exclude programmes that employ means testing but are not in fact minimum-income benefits (examples are unemployment assistance that depends on previous work status and/or contribution payments, or family benefits which are withdrawn only at medium to high income levels). Second, data quality for the main social assistance benefits is generally 
lower than for other spending categories. ${ }^{4}$ Finally, aggregate spending data cannot be broken down by age group and expenditures for the working-age population are therefore not available.

Because of these limitations, a more detailed look at institutional policy parameters is useful in order to assess the roles minimum-income benefits play in different countries. Similar measures can have very different effects depending on the institutional context in which they are used. In general, it is difficult to draw conclusions from looking at isolated measures without considering the full policy package affecting incomes and employment incentives. Table 2 lists the most important cash transfers available to the working-age group using a functional classification. ${ }^{5}$

Unemployment benefits are the main support measures for job losers and other individuals without employment. Unemployment insurance programmes exist in most OECD countries and offer compensation for lost earnings subject to work-related conditions. Reflecting insurance principles, claimants must have contributed to the insurance fund or have been employed over certain periods in order to be eligible. Claimants must also be actively looking for work and, in most cases, unemployment has to be involuntary. Benefit durations are limited in most, but not all, countries. Insurance is mandatory for most employees, but voluntary in some Nordic countries.

Job searchers whose entitlement to unemployment insurance benefits has expired, or whose work record is insufficient to make them eligible in the first place, may be entitled to unemployment assistance. In some countries, unemployment assistance is the main unemployment benefit. Eligibility is often, but not always, conditional on previous employment. As unemployment benefits, they are only available to those who are available and actively looking for work. Benefit durations may or may not be limited. While both insurance and assistance benefit schemes are typically (but, again, not universally) financed by contributions to unemployment insurance funds, the main purpose of assistance benefits is the provision of a minimum level of resources during unemployment rather than the insurance against lost earnings. As a result, benefit levels tend to be lower and less directly dependent on previous earnings. They are reduced if other incomes are available although means-testing tends to be less comprehensive than for social assistance benefits.

4. For instance, the distinction between cash, near-cash and in-kind benefits can be problematic and certain components may not be properly recorded (e.g. special payments in exceptional circumstances or other discretionary payments, such as re-employment support). Also, the decentralised delivery of minimumincome benefits can lead to incomplete reporting, or non-reporting, of spending by local authorities to central government. Importantly, non-categorical social assistance, which is the main last-resort benefit in most countries, is recorded under the "other social policy areas" heading, which may lead some countries to treat it a residual category when reporting these data.

5. Further details on eligibility and entitlement conditions for each programme are given on www.oecd.org/els/social/workincentives (using the link "tables summarizing tax-benefit policy features"). 
Table 2. Main cash benefits for able-bodied working-age individuals and their families, 2007

\begin{tabular}{|c|c|c|c|c|c|c|c|c|}
\hline & \multicolumn{2}{|c|}{ Unemployment } & \multirow{2}{*}{$\begin{array}{l}\text { Social assistance } \\
\text { (SA) (2) }\end{array}$} & \multirow{2}{*}{ Housing benefits } & \multicolumn{2}{|c|}{ Family benefits (FB) } & \multirow{3}{*}{$\begin{array}{c}\text { Lone-parent benefits } \\
\text { [7] }\end{array}$} & \multirow{3}{*}{$\begin{array}{c}\text { Employment } \\
\text { conditional benefits } \\
{[8]}\end{array}$} \\
\hline & Insurance & Assistance & & & Universal & Means-tested & & \\
\hline & [1] & [2] & {$[3]$} & [4] & [5] & [6] & & \\
\hline Australia & & $\bullet$ & $\bullet$ & $\bullet$ & & - & $\bullet$ & $\bullet$ \\
\hline Austria & - & - & - & - & - & & $\mathrm{T}$ & \\
\hline Belgium & - & - & - & & - & & $F B$ & - \\
\hline Canada & - & & - & & & - & $\mathrm{T}$ & - \\
\hline Czech Republic & - & & - & - & & - & - & \\
\hline Denmark & - & & - & - & - & & $\mathrm{FB}$ & \\
\hline Finland & - & - & - & $\bullet$ & - & & $\mathrm{FB}$ & \\
\hline France & - & - & - & - & - & - & - & - \\
\hline Germany & - & - & - & - & - & & $\mathrm{T}$ & \\
\hline Greece & - & - & & - & - & & & \\
\hline Hungary & - & - & - & - & - & & $\mathrm{FB}$ & - \\
\hline Iceland & - & & - & - & - & - & • & \\
\hline Ireland & - & - & - & SA & - & & - & - \\
\hline Italy & - & & & - & & - & $\mathrm{FB}$ & \\
\hline Japan & - & & - & - & & - & - & - \\
\hline Korea & - & & - & - & & & - & - \\
\hline Luxembourg & - & & - & - & - & & $\mathrm{T}$ & \\
\hline Netherlands & - & & - & - & - & & $\mathrm{T}$ & $\bullet$ \\
\hline New Zealand & & - & - & - & & - & • & - \\
\hline Norway & - & - & - & - & - & & • & \\
\hline Poland & - & & - & - & & • & $\mathrm{FB}$ & \\
\hline Portugal & - & - & - & & & - & $\mathrm{T}$ & \\
\hline Slovak Republic & - & & - & - & - & & & - \\
\hline Spain & - & - & - & & & - & $\mathrm{T}$ & \\
\hline Sweden & - & - & - & - & - & & - & - \\
\hline Switzerland & - & & - & - & - & & & \\
\hline United Kingdom & $\bullet$ & - & $\bullet$ & $\bullet$ & - & & & - \\
\hline United States & - & & - & & & - & $\mathrm{T}$ & • \\
\hline
\end{tabular}

Notes: (1) "Y" indicates that the specific benefit or tax credit exists in this country. Where no specific housing or lone-parent benefit is available, "SA" (social assistance), or "FB" (family benefit) indicate that housing or lone-parent specific provisions exist as part of these schemes. (2) Cash social assistance benefits only. Because of its importance, the US Food Stamps, a 'near-cash' benefit programme, is indicated as well.

Source: OECD Benefits and Wages policy database (www.oecd.org/els/social/workincentives). 
Finally, those who do not qualify for any unemployment benefit may receive social assistance benefits, with central or sub-central governments acting as providers of last resort. The main eligibility criteria therefore relate to available incomes and assets, and entitlements do not depend specifically on claimants' work history. Income and asset tests can be very restrictive and always take into account the resources of other persons living with the benefit claimant. Eligibility may be conditional on the claimant's effort to regain self-sufficiency. But while rules and practices vary substantially across countries, jobsearch and other activity requirements can be much less demanding than in the case of unemployment benefits. ${ }^{6}$ Social assistance is typically not subject to explicit time limits but is paid for as long as relevant conditions are met. Benefits often "top-up" income from other sources so as to ensure adequate income levels. Since bigger families require more resources to secure a given living standard, such top-ups are most likely when the benefit claimant has dependent family members.

In addition to the main social assistance benefits there are other government transfers that have similar characteristics or can complement or substitute for social assistance payments:

- Low-income households may also qualify for cash housing benefits, which employ similar forms of means-testing. Benefit amounts are determined in relation to actual housing costs subject to relevant ceilings. Housing benefits may be administered as separate programmes or may be payable as part of social assistance entitlements. Unlike social assistance payments, dedicated housing benefit programmes are typically not accompanied by work-related requirements or interventions that seek to re-establish self-sufficiency.

- Families with children can claim family benefits in most countries (although the definition of what constitutes a "dependent child" varies considerably). Most countries provide special benefits for lone parents either in the form of additions to regular family or childcare benefits or as separate programmes. Where benefits for children or lone parents are means-tested, they can resemble social assistance benefits in all but name. ${ }^{7}$ One difference concerns work-related activity requirements. Means-tested family benefits are frequently designed as temporary payments that enable one of the parents to spend time with their children. Apart from time limits (which can be generous and are often implicit, e.g. by specifying a maximum age for a dependent child: see Table 7), work-related behavioural requirements may therefore be minimal or nonexistent.

- Targeted income support is increasingly made available to those in work and can, to some extent, substitute for income top-ups provided by social assistance and other minimum-income benefits. Around half the OECD countries now operate employment-conditional benefits, or in-work benefits of one type or another (a few countries not shown in the table, such as Germany, have introduced such programmes since 2007). Like minimum-income benefits, some of these in-work programmes employ a family-based low-income criterion (but since they are conditional on

6. For instance, unlike unemployment benefit recipients in most countries, social assistance recipients often do not enjoy any legal job or status protection in the form of "suitable-job" criteria. Formally, they would therefore have to accept any available job although the extent to which this is enforced in practice is difficult to establish. Reasons for deviating from strict formal availability criteria may, for instance, be related to employers' concerns that pushing referrals of "overqualified" benefit claimants could damage their motivation for the job (see, e.g., Box 3 in Tergeist and Grubb, 2006).

7. In addition, several countries operate further parental-leave benefits that are not means-tested or are insurance-based (the OECD Family Database gives details: www.oecd.org/els/social/family/database). 
work, they are not payable to those without any other incomes and therefore are not benefits of last resort). ${ }^{8}$

It is clear from this overview that minimum-income benefits can be provided under a range of different policy headings. What they have in common is that they are typically received by those with no or very limited other resources of their own, and can provide a fall-back safety-net for low-income families who are not entitled to other income replacement transfers. Figure 1 situates countries' programmes along two dimensions:

(1) Rank: Main income support programme for working-age people or lower-tier benefit.

(2) Scope: Broad safety net or programme targeted at specific groups (notably lone parents).

In most countries, minimum-income programmes take the form of lower-tier fall-back benefits for those not getting any support through other measures. Last-resort benefits with a broad scope are shown in the upper right-hand corner in Figure 1. The biggest group in this category are social assistance programmes providing cash and near-cash support (US Food Stamps, since 2008 Supplemental Nutrition Assistance Program, SNAP). In addition, unemployment assistance benefits in Finland, Germany, Ireland and the UK are available independently of contribution records or previous employment history and can be counted as broad-scope lower-tier benefits. ${ }^{9}$ There are further last-resort benefits targeted at lone parents in France, the UK and the US (lower right-hand corner; although the benefit for Norwegian lone parents of young children is formally an insurance benefit, it is also included here as eligibility is subject to an income test and does not require an employment record).

In a few cases, minimum-income benefits are the main income support programme for the majority of the working-age population (upper left-hand corner of Figure 1) or for individual groups (younger individuals in Australia and lone parents in Australia, Ireland and New Zealand ${ }^{10}$ ). In addition to these first-tier programmes, Australia and New Zealand also operate lower-tier emergency benefits, but these are much less common, and are not shown here.

A small number of countries also operate targeted lower-tier minimum-income benefits that are not considered here, notably for individuals who are not able to work due to a disability, such as the US

8. For a recent summary of countries' experience with these and related “make-work-pay” programmes, see Immervoll and Pearson (2009). In some cases, in-work benefits take the form of temporary payments that are designed to increase the payoff from moving into a new job. A larger group of countries operate programmes that make recurring payments (or tax refunds) to a defined group of low-income workers for as long as other eligibility conditions are met. In order to target in-work payments to relevant groups, eligibility and benefit amounts can depend on a range of characteristics and circumstances. These include having children, working a minimum number of hours, and receiving income from work or entering/changing employment. All employment-conditional measures use at least one of these conditions or they feature gradual phase-ins or phase-outs as a means of targeting individuals at specific earnings levels or working hours. For the purpose of targeting low-income individuals, incomes can be assessed individually for the benefit recipient or jointly for the couple or the family as a whole. While irrelevant for those living alone, the assessment unit can affect benefit entitlements in larger households. Benefits that are targeted in relation to family income tend to have more favourable distributional properties. Individualbased in-work benefits are less well targeted towards poor households but avoid the adverse effect on second-earner work incentives associated with family-based benefit tapers.

9. In Ireland, unemployment assistance (Jobseekers' Allowance) is much more important than the general social assistance benefit (Supplementary Allowance).

10. The Domestic Purposes Benefit in New Zealand also provides support for some other groups, such as those caring for family members at home. 
Supplemental Security Income and the Irish Disability Allowance. In both cases, non-means-tested insurance-based programmes act as first-tier benefits. The New Zealand Invalid's Benefit and the Australian Disability Support Pension are examples of means-tested first-tier benefits targeted at this group.

Figure 1. A typology: Rank and scope of minimum-income benefits

Main out-of-work safety-net benefits for able-bodied working-age individuals and their families, 2007

\begin{tabular}{|c|c|c|}
\hline & $\begin{array}{l}\text { first-tier } \\
\text { benefit }\end{array}$ & $\begin{array}{l}\text { lower-tier } \\
\text { benefit }\end{array}$ \\
\hline $\begin{array}{l}\text { broad } \\
\text { scope }\end{array}$ & $\begin{array}{l}\text { nzl (unemployment benefit) } \\
\text { aus (newstart allowance) }\end{array}$ & $\begin{array}{l}\text { SocialAssistance: } \\
\text { aus aut bel can che } \\
\text { cze dnk esp fin fra } \\
\text { hun irl isl jpn kor } \\
\text { lux nld nor nzl pol } \\
\text { prt swe usa } \\
\text { Unemployment Assistance: } \\
\text { deu fin irl uk }\end{array}$ \\
\hline targeted & $\begin{array}{c}\text { aus (parenting payment, } \\
\text { youth allowance) } \\
\operatorname{irl} \begin{array}{c}\text { (one-parent family } \\
\text { payment) }\end{array} \\
\mathrm{nzl} \begin{array}{c}\text { (domestic purposes } \\
\text { benefit) }\end{array}\end{array}$ & $\begin{array}{l}\text { fra* (allocation de parent isolé) } \\
\text { nor (transitional benefit) } \\
\text { UK (income support) } \\
\text { USa (TANF, SSP programs) }\end{array}$ \\
\hline
\end{tabular}

* As of mid-2009, the new French Active Solidarity Income (Revenue de Solidarité Active, RSA) has been available to all low-income families, including lone parents. The Allocation de Parent Isolé (API) was abolished.

\section{Generosity: Benefit levels and related support measures}

\subsection{Benefit levels in relation to median incomes and relative poverty thresholds}

Poverty avoidance or alleviation are primary objectives of minimum-income benefits. When comparing benefit generosity across countries, a useful starting point is therefore to look at benefit levels relative to commonly-used poverty thresholds. Figure 2 presents model calculations using the OECD taxbenefit calculator. The resulting net income levels are then compared to median incomes from income distribution data. This shows that in a large majority of OECD countries for which such calculations are available, benefits of last resort can be significantly lower than the three alternative relative poverty lines ( $40 \%, 50 \%$ and $60 \%$ of median income). Individual poverty gaps are very large in some countries (there is no generally applicable social assistance benefit in Greece, Italy and Turkey) and other income sources are needed everywhere to avoid substantial poverty risks. 
In a number of countries, however, the range of possible benefit entitlements can be very wide. This is illustrated using error bars in Figure 2, which show the difference in benefit entitlements between a situation where the recipient claims no housing costs and one where she lives in privately rented accommodation and obtains partial or full compensation for housing expenditures. Housing benefit calculations in this latter case are based on a simple "high", but not unreasonably high, rent assumption across countries ( $20 \%$ of the average gross wage of a full-time worker). ${ }^{11}$ For many benefit recipients, payment levels will be somewhere in-between the "with housing costs" and "without housing costs" scenarios. In about half the countries, benefit rates show in fact little or no variation with housing costs as housing support is not available at all, is modest (for instance, there is no separate mechanism to provide cash housing support in the US Food Stamp / SNAP program but housing costs slightly reduce reckonable income in some states) or is provided on a flat-rate basis (for instance, social assistance entitlements may be designed in a way to cover "reasonable" housing costs).

Comparing across different family types, it turns out that net incomes of minimum-income recipients in families with children (second and third panel of Figure 2) tend to be higher relative to the respective poverty thresholds than for single persons (first panel). Consistent with heightened policy concerns about child poverty in many countries, this indicates that benefit provisions for children and other family members are, at least for poor households, typically more generous than would be implied by the equivalence scales typically used in income distribution studies. ${ }^{12}$

Figure 2. Income levels provided by cash minimum-income benefits

Net income value in \% of median household incomes, 2007

(a) Single, no children

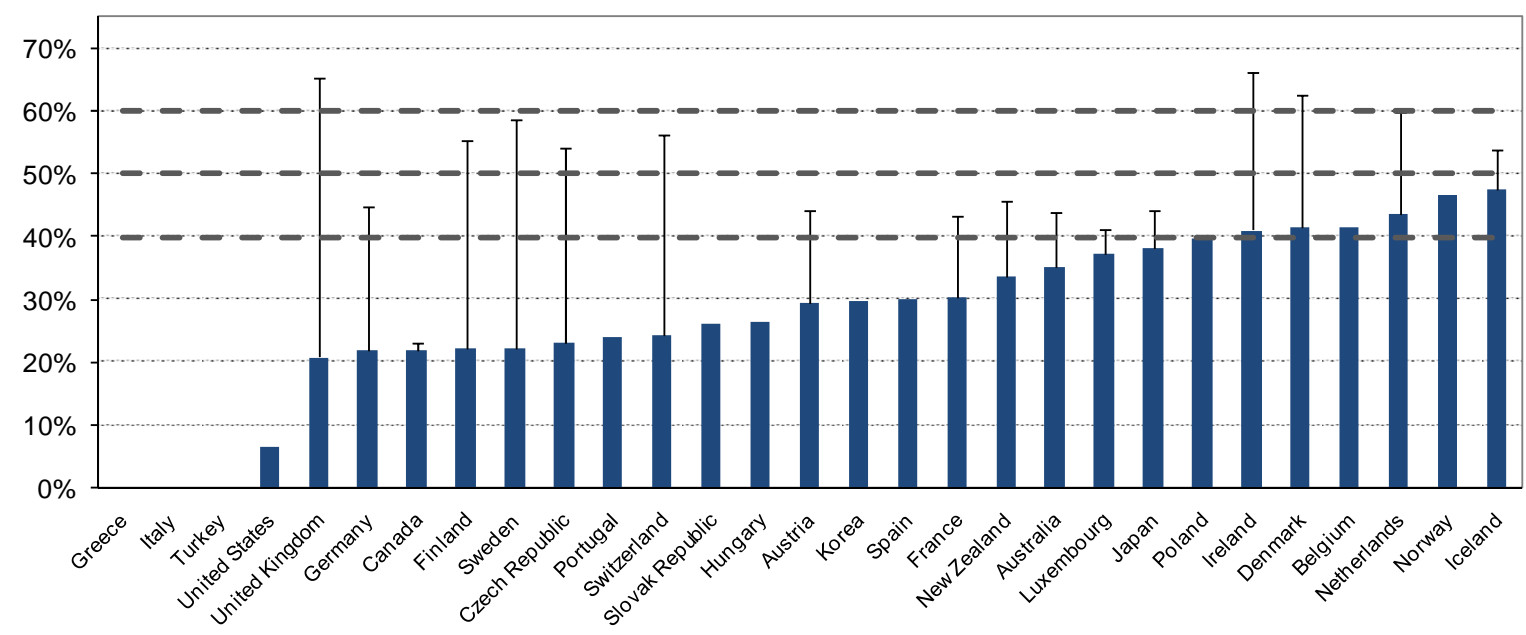

11. The assumption of $20 \%$ of AW has been motivated by an attempt to capture differences between countries that operate explicit "reasonable rent" ceilings and those that do not (or where there is a large discretionary element involved in making such decisions). In order to show this, it is necessary to choose a rent level that is sufficiently high so that relevant limits become applicable.

12. Median incomes in Figure 2 have been adjusted using the "square root of household size" scale. The weights implied the so-called "modified OECD scale", which is commonly used in Europe although not at the OECD, implies somewhat more sizable scale economies for some of the family types shown in Figure 2, but smaller ones for others. 
Figure 2 (continued)

(b) Lone parent, two children

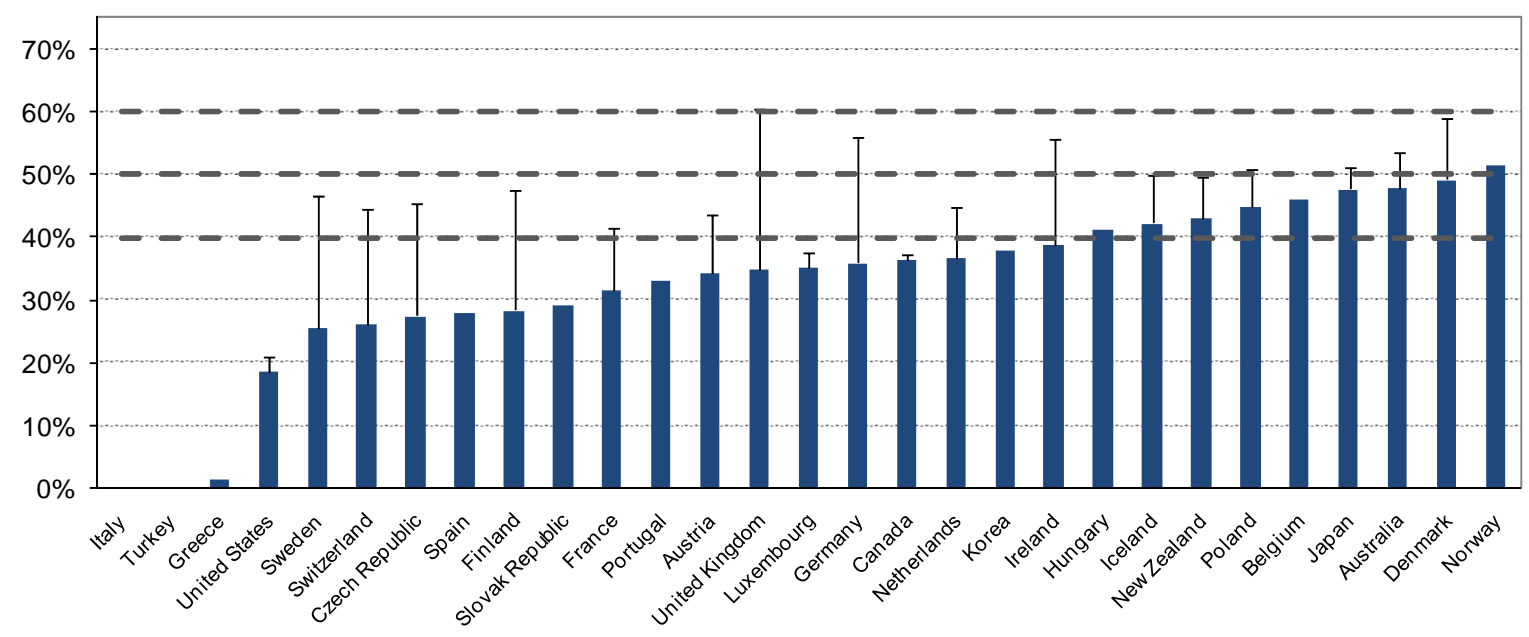

(c) Married couple, two children

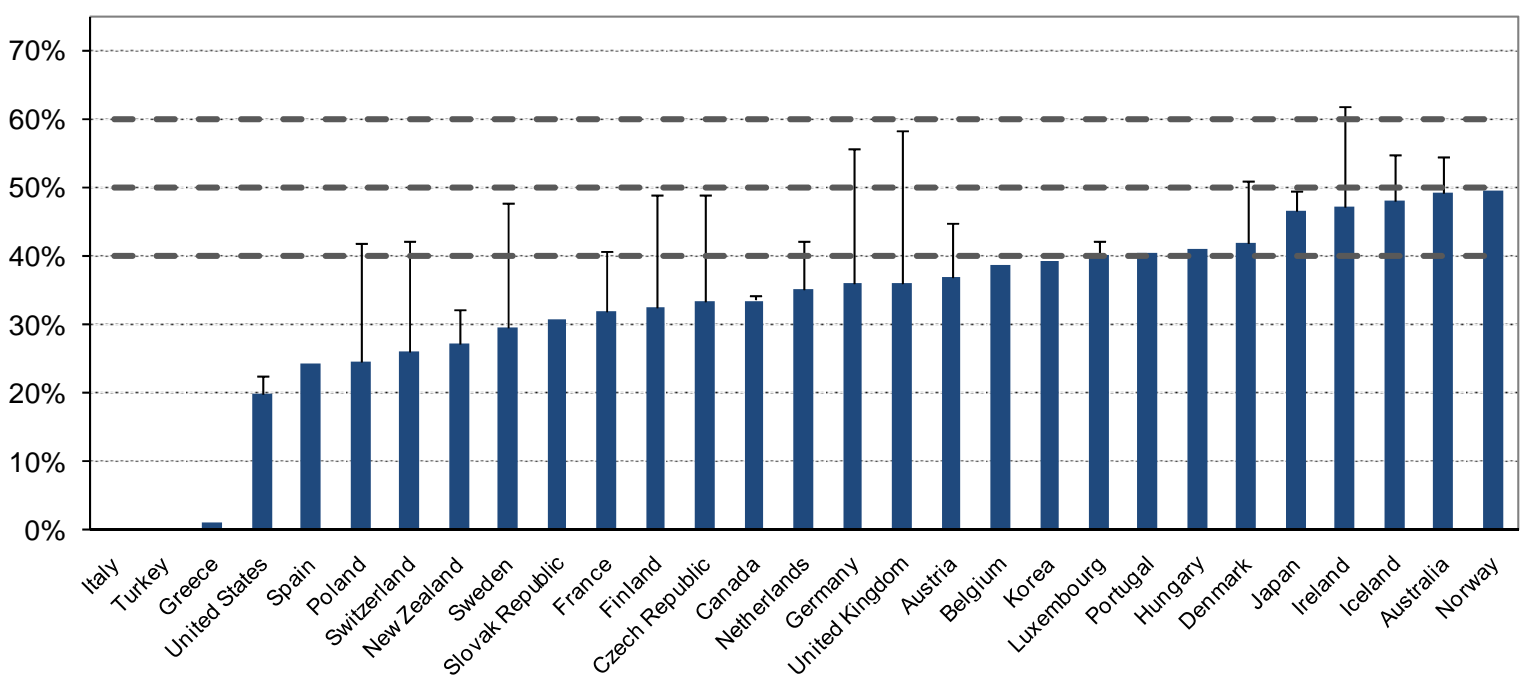

Notes: Median net household incomes are for a year around 2005 expressed in 2007 prices and are before housing costs (or other forms of "committed" expenditure). Results are shown on an equivalised basis (equivalence scale is the square root of the household size) and account for all relevant cash benefits (social assistance, family benefits, housing-related cash support as indicated). US results also include the value of Food Stamps, a near-cash benefit. Income levels account for all cash benefit entitlements of a family with a working-age head, no other income sources and no entitlements to primary benefits such as unemployment insurance. They are net of any income taxes and social contributions. Where benefit rules are not determined on a national level but vary by region or municipality, results refer to a "typical" case (e.g. Michigan in the United States, the capital in some other countries). Calculations for families with children assume two children aged 4 and 6. "Error" bars indicate the range of benefit levels in countries where they depend on actual housing expenditure. The bottom end of the error bar shows the situation where no housing costs are claimed while the top end represents cash benefits for someone in privately-rented accommodation with rent plus other charges amounting to $20 \%$ of average gross full-time wages.

Sources: OECD tax-benefit models (www.oecd.org/els/social/workincentives) and OECD income distribution database. 
Table 3. Benefit phase-outs points and benefit withdrawal rates

Single-person household, 2007

\begin{tabular}{|c|c|c|c|c|c|c|}
\hline & \multicolumn{3}{|c|}{$\begin{array}{l}\text { minimum-income benefits assuming that housing } \\
\text { expenditures are not claimed or are zero }\end{array}$} & \multicolumn{3}{|c|}{$\begin{array}{l}\text { benefits include claims for privately rented } \\
\text { accommodation expenditures, where relevant }\end{array}$} \\
\hline & $\begin{array}{c}\text { earnings, } \\
\% \text { of average } \\
\text { wage }\end{array}$ & $\begin{array}{l}\text { net income at } \\
\text { this earnings } \\
\text { level, } \\
\% \text { of median } \\
\text { household } \\
\text { income }\end{array}$ & $\begin{array}{l}\text { marginal } \\
\text { effective tax } \\
\text { rate over phase- } \\
\text { out range }\end{array}$ & $\begin{array}{c}\text { earnings, } \\
\% \text { of average } \\
\text { wage }\end{array}$ & $\begin{array}{l}\text { net income at } \\
\text { this earnings } \\
\text { level, } \\
\% \text { of median } \\
\text { household } \\
\text { income }\end{array}$ & $\begin{array}{l}\text { marginal } \\
\text { effective tax } \\
\text { rate over phase- } \\
\text { out range }\end{array}$ \\
\hline United Kingdom & 11 & 24 & 86 & 52 & 91 & 78 \\
\hline Sweden & 14 & 23 & 97 & 41 & 59 & 100 \\
\hline Canada & 17 & 24 & 90 & 17 & 25 & 90 \\
\hline Czech Republic & 17 & 23 & 100 & 86 & 105 & 62 \\
\hline Switzerland & 17 & 24 & 100 & 41 & 56 & 100 \\
\hline Hungary & 17 & 25 & 105 & 23 & 34 & 82 \\
\hline Portugal & 19 & 31 & 80 & 19 & 31 & 80 \\
\hline Finland & 19 & 28 & 82 & 44 & 61 & 88 \\
\hline Spain & 19 & 30 & 100 & 19 & 30 & 100 \\
\hline Germany & 20 & 37 & 67 & 38 & 63 & 79 \\
\hline France $^{(a)}$ & 20 & 32 & 95 & 37 & 57 & 80 \\
\hline Austria & 20 & 31 & 97 & 30 & 46 & 98 \\
\hline Korea & 22 & 40 & 76 & 22 & 40 & 76 \\
\hline Belgium & 22 & 44 & 94 & 22 & 44 & 94 \\
\hline Ireland & 23 & 42 & 98 & 41 & 75 & 100 \\
\hline Slovak Republic & 24 & 35 & 77 & 24 & 35 & 77 \\
\hline Poland & 24 & 41 & 97 & 39 & 65 & 71 \\
\hline United States & 25 & 30 & 32 & 33 & 38 & 30 \\
\hline Iceland $^{(\mathrm{b})}$ & 31 & 48 & 100 & $>150$ & & \\
\hline Japan & 32 & 51 & 79 & 32 & 51 & 89 \\
\hline Netherlands & 33 & 45 & 98 & 47 & 61 & 98 \\
\hline Norway & 34 & 48 & 98 & 34 & 48 & 98 \\
\hline Australia & 37 & 61 & 61 & 45 & 73 & 65 \\
\hline Luxembourg & 39 & 45 & 86 & 42 & 48 & 88 \\
\hline New Zealand & 45 & 59 & 66 & 70 & 90 & 61 \\
\hline Denmark $^{(b)}$ & 46 & 51 & 38 & 106 & 109 & 45 \\
\hline
\end{tabular}

Notes: See explanatory notes to Figure 2. The marginal effective tax rate (METR) is calculated over an earnings interval from zero to the respective phase-out point. It is the fraction of any additional employment incomes that is "taxed away" by the combined effects of taxes and benefits withdrawals and therefore accounts for benefit tapers as well as income taxes and social contributions payable by the benefit recipient.

a. Unlike the RMI programme shown in the table, the Revenue de Solidarité Active (RSA) which replaced RMI and API in 2009, is characterised by a flat phase-out range with marginal deduction rates of about $38 \%$. At just under $120 \%$ of the full-time minimum wage, the phase-out point for a single person is almost three times higher than under the previous programmes.

b. For Iceland, METRs are not shown in the right-hand half of the table since housing benefit are withdrawn over a very wide earnings range and METRs are therefore more driven by the tax system than by the benefit taper. To a lesser extent, the same argument can also be made in the case of Denmark.

Sources: OECD tax-benefit models (www.oecd.org/els/social/workincentives) and OECD income distribution database.

The distributional impact of minimum-income benefits is however not limited to recipient families with incomes below the levels indicated in Figure 2. Because concerns about the efficiency costs of work disincentives lead many countries to employ gradual benefit phase-outs, those with non-benefit incomes 
above the maximum benefit amounts can often still receive income top-ups. ${ }^{13}$ Table 3 illustrates this by showing the approximate earnings levels, as well as the associated net incomes, where minimum-income benefits are fully phased out.

Less than half the countries shown "fully" deduct earned incomes from benefit entitlements, with marginal effective tax rates (METRs) exceeding 90\%. Where benefits are withdrawn at a much slower rate, minimum-income benefits in some countries extend support to non-poor recipients even if they do not lift the lowest income groups out of poverty. While results are only shown for singles, it turns out that phaseout rates tend to be similar for other family types. Since benefit amounts are higher for larger families, the phase-out points are correspondingly higher up the earnings distribution in these cases. In some countries, and for some family types, income-tested in-work benefits may start being available around the earnings level where minimum-income benefits are fully phased out. In these cases, high METRs caused by benefit tapers can continue beyond the phase-out points shown in Table 3.

\subsection{Benefit levels relative to in-work incomes}

As illustrated by the METRs shown above, benefits are a key determinant of whether work "pays", especially for those with limited earnings potential. Since minimum-income recipients without any earned income mostly have net incomes below commonly-used poverty thresholds, a relevant question is how much someone would need to earn in order to escape income poverty. This amount will depend on two factors. First, higher earnings are required in countries with sizable individual "poverty gaps" (the amount by which net income falls short of the chosen poverty line). Second, the earnings necessary to reach the poverty line is determined by the part of in-work earnings that adds to household net income (and, thus, the METR).

13. The combination of benefit phase-outs and high in-work tax burdens can lead to substantial 'leaky bucket'type efficiency losses and, hence, very high marginal costs of redistributing extra amounts to the poor by raising minimum-income benefits. For instance, calculations for $15 \mathrm{EU}$ countries reported by Immervoll et al. (2007) show that in countries with relatively generous existing welfare provisions, it typically costs 2.5 euros or more to redistribute an extra euro in this way. However, the same calculations also indicate considerable scope for improving safety-nets where they are currently less developed. This is notably the case in some Southern European countries, where the costs of improving minimum-income provisions are much lower. 
Figure 3. Net incomes of benefit recipients and full-time minimum-wage earners

in \% of median household incomes, 2007

(a) Single, no children

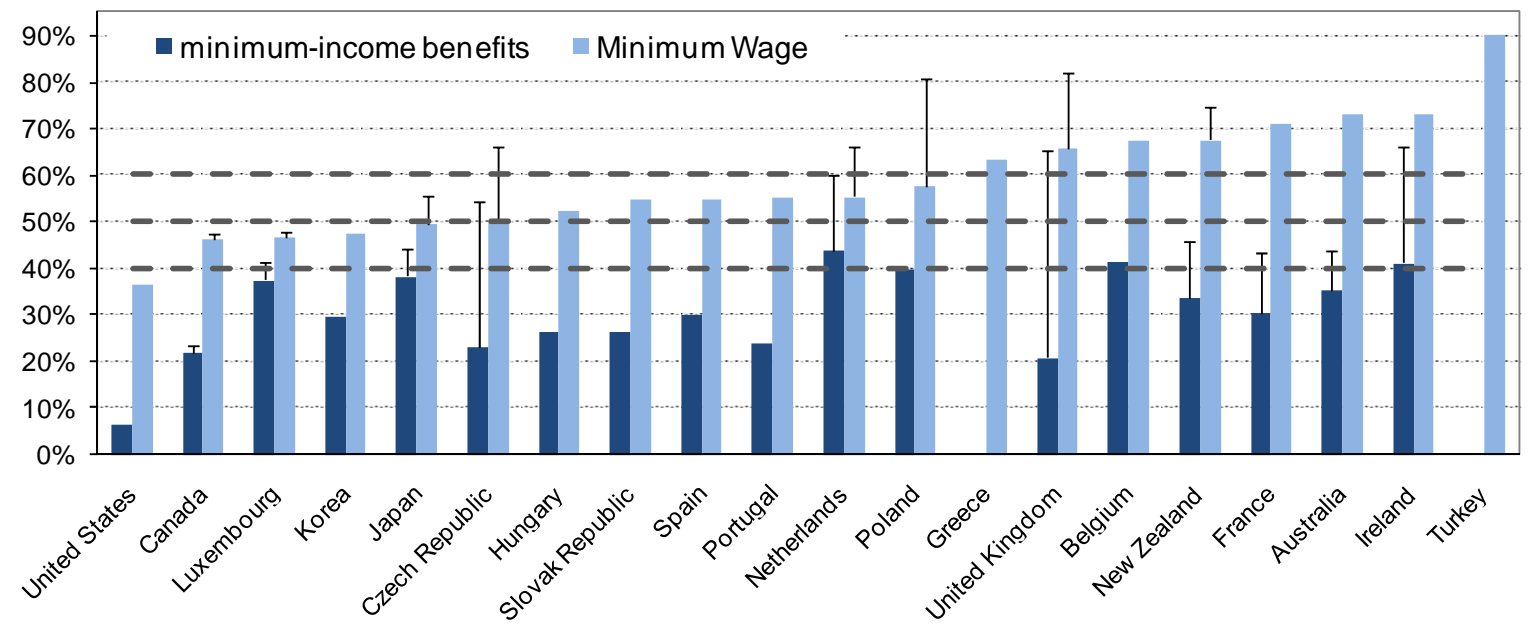

Figure 3 (continued)

(b) Lone parent, two children

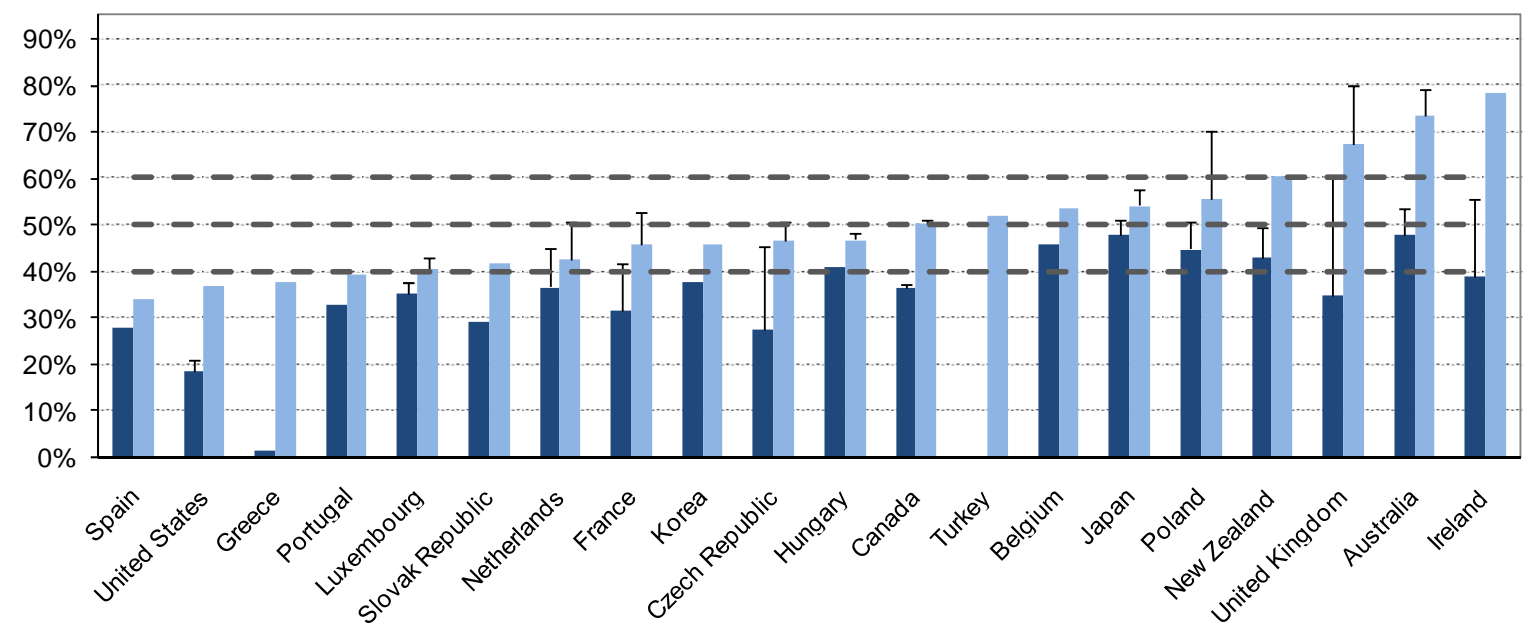


(c) Married couple, two children

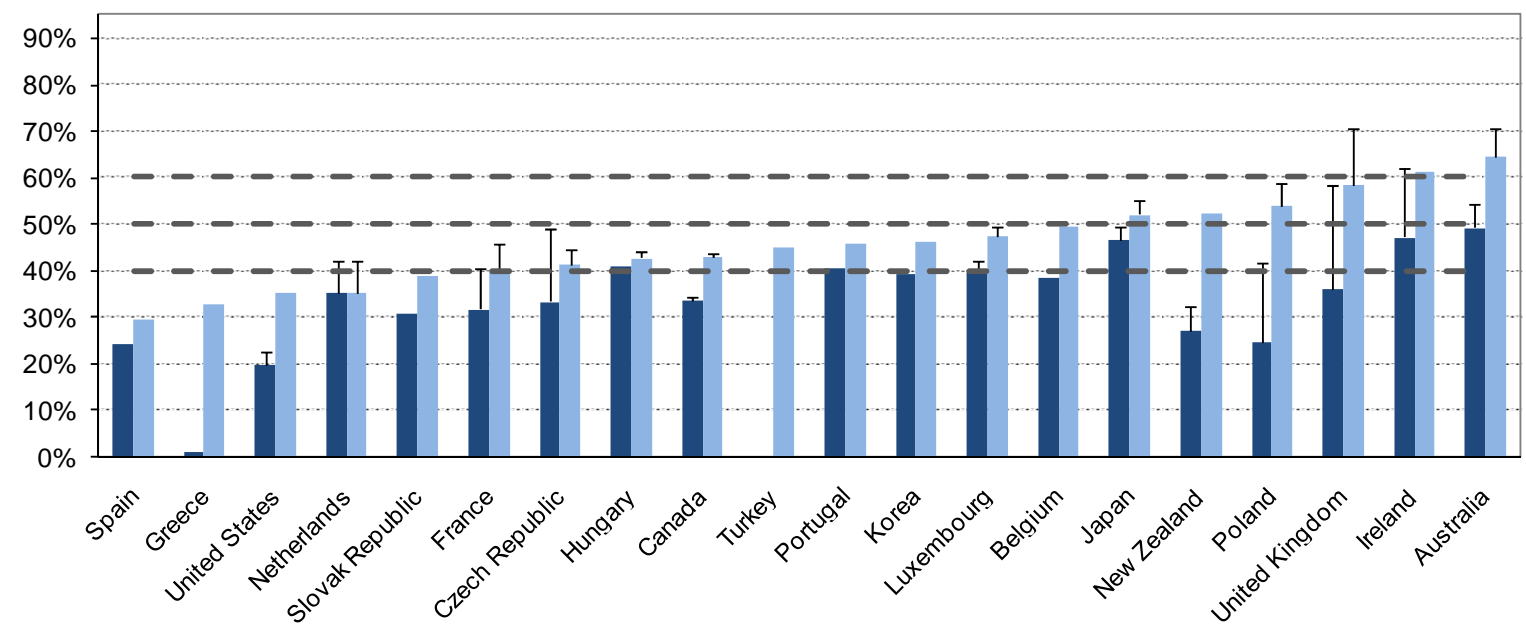

Note: See explanatory notes to Figure 2. Hourly minimum wages are converted to monthly earnings based on 40 working hours per week. Where minimum wages depend on age, profession or sector, figures relate to the adult rate for white-collar workers in the private sector (Belgium, Greece, Portugal). The federal minimum is used for the US. Where there is no country-wide minimum, weighted averages of regional minimum wages are used (Japan). Incomes in the married-couple case are calculated assuming that there is only one earner.

Sources: OECD tax-benefit models (www.oecd.org/els/social/workincentives), OECD income distribution database and OECD minimum wage database.

One way of showing the situation of low-wage earners is by reference to minimum wages. In around two thirds of the OECD countries, wages are subject to statutory minima. Comparisons based on gross minimum wage levels do not take into account differences in taxes and benefits and can therefore give only a partial indication about the true value of wage floors. Figure 3 shows incomes of full-time employees earning the statutory minimum wage after taxes and benefits and, as the earlier Figure 2, relates those to median household disposable income. ${ }^{14}$ In the majority of countries, a full-time minimum-wage earner in a single-person household makes enough to put her above $50 \%$ of median household income and with the exception of the United States, full-time minimum-wage earnings are everywhere sufficient to ensure incomes above the $40 \%$ threshold (net incomes can be higher in the considerable number of states that operate statutory minima exceeding the US federal minimum wage).

In the case of families, one minimum-wage job is typically not enough to escape relative poverty using the 50\% threshold. However, in-work benefits and/or gradual benefit phase-out rates for families with children can provide a significant income boost. For instance, a lone-parent full-time minimum-wage worker in New Zealand, UK, Australia and Ireland takes home net income at or above $60 \%$ of median incomes. The net income gain from working in a full-time job typically exceeds $20 \%$. But in a number of cases, the income gain is in fact quite limited, even if minimum wages are high (e.g. France, Luxembourg, Netherlands). Work incentive problems can especially be a problem for those entitled to housing-related benefits (as in Figure 2, such entitlements are indicated by the error bars). Finally, it is important to note that these income figures are before childcare costs. Even with relatively large income gains, lone parents with children requiring care may still consider that a full-time job does little to improve the family budget and that they are financially better off on benefits (OECD, 2007b, discusses childcare costs and work incentives in detail).

14. OECD (2007a) analyses the tax treatment of minimum wages on both the employee and employer side. 
In general, the earnings needed to reach the poverty line increase with increasing family size, so that net incomes of lone-parent minimum-wage earners tend to be lower in relation to median incomes than for childless singles. But patterns differ across countries both in quantitative and in qualitative terms. For instance, while support for families with children is often structured in such a way as to make it easier for them to escape poverty than for their childless counterparts (e.g., Australia, Ireland, New Zealand and the United Kingdom), the reverse appears to be true in a few other countries (e.g., Spain, US).

\subsection{Benefit levels relative to unemployment benefits}

Minimum-income benefits form an integral part of the redistribution system. In setting benefit amounts, policymakers need to consider not only poverty thresholds and the income position of low-wage workers, but also the levels of other, higher-tier benefit payments. Where minimum-income programs act as fall-back benefits for people not (or no longer) entitled to unemployment compensation, their generosity has important implications for the functioning of unemployment benefits.

For instance, as a measure to facilitate effective job-search, unemployment benefit recipients are typically confronted with declining benefit payments or expiring entitlement once they have been out of work for a specified period. Such "threat points" reinforce job-search incentives and have been shown to improve job-finding rates, even before benefits are reduced. ${ }^{15}$ But whether these measures have their intended effect depends in part on the existence and generosity of minimum-income benefits that may top up unemployment benefits, or substitute for them entirely. Such interactions may or may not be intended. One the one hand, substitution can be a concern as the required contact intensity with case workers is typically lower, and job-search requirements less demanding, for social assistance claimants than for those claiming unemployment benefits.

15. This effect has been documented in numerous stuies in the US (Card and Levine, 2000; Katz and Meyer, 1990) as well as in Europe (Roed and Zhang, 2003; Lalive et al., 2006). However, more recently, a few authors have questioned whether this phenomenon is as economically significant as the earlier studies appear to indicate (Card et al., 2007; Boon and van Ours, 2009). 
Table 4. Minimum-income benefit levels relative to unemployment benefits ${ }^{(1)}$

2007, in percent, for two different levels of previous earnings and at different points during an unemployment spell

\begin{tabular}{|c|c|c|c|c|c|c|c|c|c|}
\hline & \multirow{3}{*}{$\begin{array}{c}\text { point during } \\
\text { unemployment } \\
\text { spell } \\
\text { [months] }^{(2)}\end{array}$} & \multicolumn{4}{|c|}{ below-average earner ( $67 \%$ of $A W)$} & \multicolumn{4}{|c|}{ average earner $(100 \%$ of $A W)$} \\
\hline & & \multicolumn{2}{|c|}{ No children } & \multicolumn{2}{|c|}{$\begin{array}{c}2 \text { children } \\
\text { (ages } 4 \text { and } 6 \text { ) }\end{array}$} & \multicolumn{2}{|c|}{ No children } & \multicolumn{2}{|c|}{$\begin{array}{c}2 \text { children } \\
\text { (ages } 4 \text { and } 6 \text { ) }\end{array}$} \\
\hline & & $\begin{array}{l}\text { single } \\
\text { person }\end{array}$ & $\begin{array}{l}\text { 1-earner } \\
\text { couple }\end{array}$ & $\begin{array}{l}\text { lone } \\
\text { parent }\end{array}$ & $\begin{array}{l}\text { 1-earner } \\
\text { couple }\end{array}$ & $\begin{array}{l}\text { single } \\
\text { person }\end{array}$ & $\begin{array}{l}\text { 1-earner } \\
\text { couple }\end{array}$ & $\begin{array}{l}\text { lone } \\
\text { parent }\end{array}$ & $\begin{array}{l}\text { 1-earner } \\
\text { couple }\end{array}$ \\
\hline Australia & $1+$ & 100 & 100 & 100 & 100 & 100 & 100 & 100 & 100 \\
\hline \multirow{2}{*}{ Austria } & $1-9$ & 91 & 114 & 97 & 113 & 66 & 84 & 79 & 92 \\
\hline & $10+$ & 99 & 124 & 103 & 119 & 72 & 91 & 84 & 97 \\
\hline \multirow{2}{*}{ Belgium } & $1-12$ & 61 & 81 & 91 & 87 & 61 & 81 & 91 & 87 \\
\hline & $13+$ & 73 & 81 & 89 & 85 & 73 & 81 & 89 & 85 \\
\hline Canada & $1-8$ & 49 & 75 & 80 & 85 & 36 & 55 & 64 & 68 \\
\hline Czech Republic & $1-6$ & 92 & 120 & 98 & 122 & 76 & 100 & 88 & 106 \\
\hline Denmark & $1-48^{(3)}$ & 97 & 89 & 94 & 103 & 97 & 89 & 94 & 103 \\
\hline \multirow{2}{*}{ Finland } & $1-23^{(3)}$ & 92 & 107 & 79 & 110 & 87 & 98 & 74 & 104 \\
\hline & $24+$ & 122 & 140 & 94 & 141 & 122 & 140 & 94 & 142 \\
\hline \multirow{2}{*}{ France } & $1-23$ & 70 & 91 & 86 & 97 & 51 & 65 & 71 & 80 \\
\hline & $24+$ & 105 & 121 & 111 & 125 & 105 & 121 & 111 & 125 \\
\hline Germany & $1-12$ & 79 & 99 & 107 & 106 & 58 & 76 & 92 & 90 \\
\hline \multirow{3}{*}{ Hungary } & $1-3$ & 42 & 73 & 75 & 89 & 39 & 68 & 72 & 85 \\
\hline & $4-9$ & 70 & 127 & 107 & 127 & 70 & 127 & 107 & 127 \\
\hline & $10-12$ & 102 & 185 & 130 & 156 & 102 & 185 & 130 & 156 \\
\hline \multirow{2}{*}{ Iceland } & $1-4$ & 81 & 113 & 85 & 108 & 70 & 93 & 78 & 94 \\
\hline & $5-36$ & 92 & 135 & 90 & 118 & 92 & 135 & 90 & 118 \\
\hline Ireland & $1-15$ & 100 & 100 & 100 & 100 & 100 & 100 & 100 & 100 \\
\hline Japan & $1-9$ & 64 & 92 & 107 & 134 & 54 & 78 & 103 & 115 \\
\hline Korea & $1-7$ & 45 & 73 & 97 & 119 & 34 & 55 & 75 & 89 \\
\hline Luxembourg & $1-12$ & 70 & 97 & 79 & 100 & 50 & 67 & 58 & 73 \\
\hline \multirow{2}{*}{ Netherlands } & $1-2$ & 103 & 106 & 90 & 101 & 73 & 89 & 79 & 88 \\
\hline & $3-22$ & 108 & 109 & 92 & 102 & 78 & 94 & 83 & 92 \\
\hline New Zealand & $1+$ & 100 & 100 & 100 & 100 & 100 & 100 & 100 & 100 \\
\hline \multirow{2}{*}{ Norway } & $1-24$ & 80 & 111 & 92 & 134 & 60 & 85 & 83 & 106 \\
\hline & $24+$ & 80 & 111 & 92 & 134 & 60 & 85 & 83 & 106 \\
\hline \multirow{2}{*}{ Poland } & $1-12$ & 54 & 76 & & & 54 & 76 & & \\
\hline & $1-18^{(4)}$ & & & 77 & 97 & & & 77 & 97 \\
\hline \multirow{2}{*}{ Portugal } & $1-28$ & 30 & 60 & 65 & 92 & 20 & 40 & 45 & 65 \\
\hline & $29-42$ & 56 & 89 & 91 & 129 & 56 & 89 & 91 & 129 \\
\hline Slovak Republic & $1-6$ & 46 & 76 & 77 & 93 & 31 & 51 & 54 & 65 \\
\hline \multirow{2}{*}{ Spain } & $1-6$ & 43 & 54 & 64 & 72 & 38 & 46 & 47 & 51 \\
\hline & $7-24$ & 49 & 63 & 75 & 84 & 38 & 46 & 54 & 60 \\
\hline \multirow{2}{*}{ Sweden } & $1-9^{(3)}$ & 84 & 105 & 71 & 105 & 84 & 105 & 71 & 105 \\
\hline & $10-28$ & 93 & 116 & 74 & 111 & 84 & 105 & 71 & 105 \\
\hline Switzerland & $1-18$ & 87 & 110 & 97 & 109 & 68 & 84 & 69 & 78 \\
\hline United Kingdom & $1-6$ & 100 & 100 & 100 & 100 & 100 & 100 & 100 & 100 \\
\hline United States & $1-6^{(5)}$ & 14 & 25 & 73 & 90 & 11 & 19 & 57 & 71 \\
\hline
\end{tabular}

Notes:

(1) Housing-related support is included in the net incomes of both the unemployment and minimum-income recipients (using housing-cost assumptions as explained in the notes to Figure 2). Greece, Italy, Mexico and Turkey are not shown as they do not operate broad minimum-income cash-benefit programmes (nor, in the case of Mexico, a generally available unemployment benefit system). (2) The period indicates the maximum duration of unemployment benefits for a 40-year old worker with a 'long' employment and contribution record. Separate periods are shown for each successive benefit programme (e.g. insurance and assistance benefits) or if benefit levels in a given programme decline during the entitlement period. (3) Membership in the unemployment insurance fund is voluntary. (4) Unemployment benefit durations are longer for families with children. (5) Unemployment benefit durations are longer in states where the unemployment rate exceeds a specified level.

AW denotes the average wage of a full-time worker in industry sectors C-K (ISIC Revision 3.1).

Source: OECD tax-benefit models (www.oecd.org/els/social/workincentives). 
On the other hand, the balance of the two main objectives of unemployment compensation (facilitating job search and providing a degree of income security) may change depending on the labourmarket situation. For instance, as job vacancies dry up during a recession, and demand-side restrictions become more binding, job-search incentives may be less effective and concerns about the adequacy of income support for the growing number of longer-term unemployed may become more pressing. In this case, the existence and availability of minimum-income benefits may provide a welcome mechanism that provides additional protection for job searchers and their families.

Table 4 shows income levels of minimum-income recipients relative to those provided by unemployment benefits. Where unemployment benefits are paid at different rates depending on the duration of unemployment, separate lines are shown for each possible benefit level. Unsurprisingly, ratios between minimum-income and unemployment benefits tend to be higher for those experiencing declining unemployment benefits during a longer unemployment spell, notably in countries operating both unemployment insurance and assistance benefits (see Table 2). In most cases, however, initial unemployment benefits provide incomes that are significantly above minimum-income levels. The gap between the two is greatest in Hungary and Poland, Japan and Korea, Portugal and Spain, as well as Canada and the United States - especially for unemployed individuals living alone. However, for those with below-average previous earnings, some earnings-related unemployment insurance benefits can be quite close to, or even below, the level of social assistance or other minimum-income benefits. This is the case for one-earner couples in a number of continental and all northern European countries, as well as in the Czech Republic.

In countries where minimum-income benefits are at the same time the main out-of-work benefit, the ratios are $100 \%$ (Australia, New Zealand). The same is true for Ireland and the UK, where eligible jobseekers are entitled to a flat-rate insurance benefit during an initial period of unemployment and the follow-up assistance benefit is paid at the same level as long as the family has no other incomes.

A ratio of minimum-income to unemployment benefit levels above $100 \%$ provides an indication of the potential importance of minimum-income payments as top-up benefits for those with low unemployment benefit entitlements. ${ }^{16}$ This can provide useful contextual information for understanding the characteristics of benefit recipients. For instance, for most family types, the net incomes provided by the Finnish Basic Allowance and Labour Market Support benefits (paid to jobseekers who are not - or no longer - entitled to earnings-related unemployment insurance payments) tend to be below social assistance levels. As a result, about $40 \%$ of social assistance recipients are receiving these unemployment benefits at the same time (STAKES, 2008). Since they are therefore already registered as jobseekers and have access to relevant support from the Public Employment Service, this has important implications for the scope of reintegration services to be provided by the social assistance administration.

\subsection{Related support measures: Health-care}

In addition to cash support, countries operate a number of further programmes to address the needs of social-assistance clients. This includes 'near-cash' or in-kind support which may provide help with basic consumption items on a regular or case-by-case basis (such as for food, clothing, housing or transport), as well as assistance that seeks to promote reintegration and self-sufficiency (such as education, training, or rehabilitation measures).

16. In combination with the income levels of minimum-income recipients relative to the poverty line in Figure 2, it also indicates the extent to which unemployment benefit claimants are likely to be affected by income poverty. 
Access to healthcare is one type of support that is especially important for the current and future wellbeing of benefit clients and their families. Where employment barriers are health-related, it is also an essential component of reintegration and rehabilitation strategies. Because of the high cost of health-related services and products, support in this area can make a big difference to the living standard and the work incentives of benefit recipients.

Table 5 summarises responses to a recent questionnaire on health-related support sent to responsible government departments in OECD member countries. This questionnaire collected information on basic healthcare coverage of benefit recipients and low-income groups, including those in irregular or low-paid work. It covered support for meeting the cost of health coverage, as well as help with out-of-pocket payments, such as deductibles or copayments. This latter category is important because out-of-pocket expenses for hospitalisation, doctor visits or items such as eye-glasses or dental products, can be high relative to the budgets of low-income families, even if these families are covered under the basic healthcare scheme.

Where basic healthcare is financed out of general tax revenues, coverage is universal with citizenship or residence being the only condition for access (Australia, Canada, Denmark, Iceland, New Zealand, Norway, Portugal, Spain, Sweden, United Kingdom). As a result, benefit recipients, as well as other lowincome groups, are automatically covered and help with paying for coverage is not needed (in Australia, a medical levy is administered as part of the income tax and this payment is not due for low-income individuals). However, most of these countries provide help with meeting out-of-pocket expenditures for low-income groups (Australia, Denmark, Iceland) or recipients of unemployment benefits ('UB' in the table) or social assistance ('SA').

Where healthcare is insurance-based, membership in public or private insurance programmes may be mandatory so that coverage can also be de facto universal (Czech Republic, Finland, Japan, Korea, Netherlands, Switzerland). Where this is not the case, uninsured family members, such as those without work, can be covered alongside an insured person at no additional cost (Belgium, France, Germany, Greece, Luxembourg, Poland). Yet, in a number of countries, those with low or irregular employment incomes may not be covered on a mandatory basis, although they generally have the option of contributing (Austria, Belgium, Germany, Luxembourg, Poland). In the United States, a large proportion of workers are not covered by employment-based insurance, and often have income too high to be eligible for statesupported programmes.

In almost all OECD countries, benefit recipients are normally covered automatically at no or reduced cost. Such concessions are often lost when moving to a low-wage job (e.g. France, Germany, Hungary, Japan), although contributions in most countries are a percentage of earnings and are therefore lower for low-paid workers. In more than a third of the countries surveyed, benefit recipients (as well as low-income groups) are also entitled to lower out-of-pocket payments for medical goods or services. In the United States, there is no automatic health coverage for benefit recipients (Medicaid, the main public programme for low-income working-age individuals, covered about $40 \%$ of those below the official poverty line in 2007).

In a number of countries, health-related support for benefit recipients is financed directly by the relevant benefit agency (bottom of Table 5). Funding arrangements that oblige benefit-paying institutions to bear the cost of these support measures can reinforce incentives for these institutions to seek to reduce benefit dependency. 
Table 5. Health-related support for benefit recipients and low-income groups

\begin{tabular}{|c|c|c|c|c|c|c|c|c|}
\hline & Australia & Austria & Belgium & Canada & Czech Republic & Denmark & Finland & France \\
\hline Basic health coverage & $\begin{array}{c}\text { public } \\
\text { (tax-financed) }\end{array}$ & $\begin{array}{c}\text { public } \\
\text { (insurance-based) }\end{array}$ & $\begin{array}{c}\text { public } \\
\text { (insurance-based) }\end{array}$ & $\begin{array}{c}\text { public } \\
\text { (tax-financed) }\end{array}$ & $\begin{array}{c}\text { public } \\
\text { (insurance-based) }\end{array}$ & $\begin{array}{c}\text { public } \\
\text { (tax-financed) }\end{array}$ & $\begin{array}{c}\text { public } \\
\text { (insurance-based) }\end{array}$ & $\begin{array}{c}\text { public } \\
\text { (insurance-based) }\end{array}$ \\
\hline 'univeral' coverage & yes & no & no & yes & yes & yes & yes & yes \\
\hline $\begin{array}{l}\text { derived rights for uninsured family } \\
\text { members }\end{array}$ & $\mathrm{n} / \mathrm{a}$ & $\begin{array}{c}\text { yes } \\
\text { (may cost more) }\end{array}$ & yes & $\mathrm{n} / \mathrm{a}$ & $\mathrm{n} / \mathrm{a}$ & $\mathrm{n} / \mathrm{a}$ & $\mathrm{n} / \mathrm{a}$ & $\begin{array}{c}\text { yes } \\
\text { (at no cost) }\end{array}$ \\
\hline $\begin{array}{l}\text { potentially not covered } \\
\text { (e.g. groups who do not have to } \\
\text { contribute on a mandatory basis) }\end{array}$ & $\mathrm{n} / \mathrm{a}$ & $\begin{array}{l}\text { if earnings < } \\
\text { contribution } \\
\text { threshold }\end{array}$ & $\begin{array}{l}\text { if earnings < } \\
\text { contribution } \\
\text { threshold }\end{array}$ & $\mathrm{n} / \mathrm{a}$ & $\mathrm{n} / \mathrm{a}$ & $\mathrm{n} / \mathrm{a}$ & $\mathrm{n} / \mathrm{a}$ & $\mathrm{n} / \mathrm{a}$ \\
\hline \multicolumn{9}{|l|}{ Concessions 1: Insurance cost } \\
\hline low -income individuals & $\begin{array}{l}\text { no medicare } \\
\text { levy if income } \\
\text { below threshold }\end{array}$ & $\begin{array}{c}\text { reduced } \\
\text { contributions (ow } \mathrm{n} \\
\text { and family members) }\end{array}$ & $\begin{array}{l}\text { reduced or no } \\
\text { contributions }\end{array}$ & $\mathrm{n} / \mathrm{a}$ & -- & $\mathrm{n} / \mathrm{a}$ & no & no \\
\hline benefit recipients & no & $\begin{array}{l}\text { registered } \\
\text { unemployed }\end{array}$ & UB & $\mathrm{n} / \mathrm{a}$ & $\begin{array}{c}\text { registered } \\
\text { unemployed; recipients } \\
\text { of maternity benefits }\end{array}$ & $\mathrm{n} / \mathrm{a}$ & no & $\begin{array}{l}\mathrm{SA}, \mathrm{UB} \text { (subject to } \\
\text { income limit) }\end{array}$ \\
\hline other & -- & -- & -- & $\mathrm{n} / \mathrm{a}$ & $\begin{array}{l}\text { adults caring for a } \\
\text { child up to age } 4 .\end{array}$ & $\mathrm{n} / \mathrm{a}$ & no & $\begin{array}{l}\text { no (but employers } \\
\text { often entitled to } \\
\text { reduced contributions, } \\
\text { e.g. certain regions or } \\
\text { groups of w orkers) }\end{array}$ \\
\hline $\begin{array}{l}\text { different coverage for those paying } \\
\text { preferential rates? }\end{array}$ & no & no & no & $n / a$ & no & $\mathrm{n} / \mathrm{a}$ & $\mathrm{n} / \mathrm{a}$ & no \\
\hline \multicolumn{9}{|l|}{ Concessions 2: Out-of-pocket } \\
\hline low -income individuals & yes & yes & yes & no & $\begin{array}{l}\text { no (but system of user } \\
\text { fees introduced in '08) }\end{array}$ & $\begin{array}{l}\text { health and dental } \\
\text { treatment; } \\
\text { pharmaceuticals }\end{array}$ & no & $\begin{array}{l}\text { yes (free or subsidised } \\
\text { complementary } \\
\text { coverage) }\end{array}$ \\
\hline benefit recipients & yes (automatic) & SA & $\begin{array}{l}\text { UB recipients aged } \\
50+\text { (subject to } \\
\text { means test) }\end{array}$ & $\begin{array}{c}\text { SA (for } \\
\text { prescription drugs) }\end{array}$ & $\begin{array}{l}\text { no (but system of user } \\
\text { fees introduced in '08) }\end{array}$ & $\mathrm{n} / \mathrm{a}$ & SA & $\begin{array}{l}\text { SA, UB (subject to } \\
\text { income limit) }\end{array}$ \\
\hline other & -- & -- & -- & $\begin{array}{l}\text { First Nations and } \\
\text { eligible Inuit (for } \\
\text { prescription drugs) }\end{array}$ & -- & $\begin{array}{c}\text { exemptions for } \\
\text { individuals with } \\
\text { substantial impairment, } \\
\text { social problems }\end{array}$ & $\begin{array}{c}\text { ceilings for annual out- } \\
\text { of-pocket } \\
\text { expenditures }\end{array}$ & -- \\
\hline \multicolumn{9}{|l|}{ Financing of concessions } \\
\hline low-income individuals & central gov't & $\begin{array}{l}\text { health insurance } \\
\text { institution }\end{array}$ & $\begin{array}{l}\text { health insurance } \\
\text { institution }\end{array}$ & $\mathrm{n} / \mathrm{a}$ & -- & $\begin{array}{l}\text { municipality, central } \\
\text { gov't }\end{array}$ & -- & $\begin{array}{l}\text { central gov't; insurance } \\
\text { institution; private } \\
\text { insurance providers }\end{array}$ \\
\hline benefit recipients & -- & UB: PES; SA: state & see above & provincial gov'ts & central gov't & $\mathrm{n} / \mathrm{a}$ & -- & same as above \\
\hline other & -- & -- & -- & central gov't & -- & $\begin{array}{l}\text { municipality, } 50 \% \\
\text { reimbursed by central } \\
\text { gov't }\end{array}$ & $\begin{array}{l}\text { central gov't subsidies } \\
\text { to municipalities (vary } \\
\text { w ith local unemp. rate) }\end{array}$ & central gov't \\
\hline
\end{tabular}


Table 5 (continued). Health-related support for benefit recipients and low-income groups

\begin{tabular}{|c|c|c|c|c|c|c|}
\hline & Germany & Greece & Hungary & Iceland & Japan & Korea \\
\hline Basic health coverage & $\begin{array}{c}\text { public } \\
\text { (insurance-based) }\end{array}$ & $\begin{array}{c}\text { public } \\
\text { (insurance-based) }\end{array}$ & $\begin{array}{c}\text { public } \\
\text { (insurance-based) }\end{array}$ & $\begin{array}{c}\text { public } \\
\text { (tax-financed) }\end{array}$ & $\begin{array}{c}\text { public } \\
\text { (insurance-based) }\end{array}$ & $\begin{array}{c}\text { public } \\
\text { (insurance- }\end{array}$ \\
\hline 'univeral' coverage & no & no & no & yes & yes & yes \\
\hline $\begin{array}{l}\text { derived rights for uninsured family } \\
\text { members }\end{array}$ & $\begin{array}{l}\text { yes (at no cost, except } \\
\text { high incomes) }\end{array}$ & $\begin{array}{c}\text { yes } \\
\text { (at no cost) }\end{array}$ & $\begin{array}{c}\text { no } \\
\text { (as of } 1 \text { April, } 08 \text { ) }\end{array}$ & $\mathrm{n} / \mathrm{a}$ & $\begin{array}{c}\text { yes } \\
\text { (at no cost) }\end{array}$ & $\begin{array}{c}\text { yes } \\
\text { (at no cost) }\end{array}$ \\
\hline $\begin{array}{l}\text { potentially not covered } \\
\text { (e.g. groups w ho do not have to } \\
\text { contribute on a mandatory basis) }\end{array}$ & $\begin{array}{l}\text { (i) if earnings < contrib. } \\
\text { threshold; (ii) if } \\
\text { earnings > upper limit }\end{array}$ & $\begin{array}{l}\text { unemployed with short } \\
\text { contrib. histories (but } \\
\text { then covered under in- } \\
\text { kind health insurance) }\end{array}$ & . & $\mathrm{n} / \mathrm{a}$ & -- & $\mathrm{n} / \mathrm{a}$ \\
\hline \multicolumn{7}{|l|}{ Concessions 1: Insurance cost } \\
\hline low -income individuals & $\begin{array}{l}\text { reduced minimum } \\
\text { payment for low - } \\
\text { income self-employed }\end{array}$ & no & $\begin{array}{l}\text { individuals in 'social need', } \\
\text { e.g. the homeless }\end{array}$ & $\mathrm{n} / \mathrm{a}$ & $\begin{array}{c}\text { reduction of up to } \\
70 \%\end{array}$ & no \\
\hline benefit recipients & $\begin{array}{l}\text { UB \& SA (if insured } \\
\text { before claiming) }\end{array}$ & no & $\begin{array}{l}\text { recipients of insurance, } \\
\text { assistance, and family } \\
\text { benefits }\end{array}$ & $\mathrm{n} / \mathrm{a}$ & $\begin{array}{l}\text { SA: exempt from } \\
\text { contributions }\end{array}$ & no \\
\hline other & $\begin{array}{l}\text { recipients of maternity } \\
\text { and parental-leave } \\
\text { benefits (if insured } \\
\text { before) }\end{array}$ & no & -- & $\mathrm{n} / \mathrm{a}$ & no & $\begin{array}{l}\text { disabled, old- } \\
\text { age }(65+), \\
\text { individuals } \\
\text { living in remote } \\
\text { areas }\end{array}$ \\
\hline $\begin{array}{l}\text { different coverage for those paying } \\
\text { preferential rates? }\end{array}$ & no & $\mathrm{n} / \mathrm{a}$ & no & $\mathrm{n} / \mathrm{a}$ & no & no \\
\hline \multicolumn{7}{|l|}{ Concessions 2: Out-of-pocket } \\
\hline low-income individuals & $\begin{array}{l}\text { annual copayments } \\
\text { capped at } 2 \% \text { of } \\
\text { household income }\end{array}$ & no & $\begin{array}{l}\text { possible exemptions (e.g. } \\
\text { for low -income elderly) }\end{array}$ & yes & -- & no \\
\hline benefit recipients & $\begin{array}{l}\text { as above, plus refund } \\
\text { for } \\
\text { pregnancy/childbirth }\end{array}$ & no & no & $\begin{array}{l}\text { recipients of } \\
\text { maternity or } \\
\text { parental-leave }\end{array}$ & -- & no \\
\hline other & -- & no & $\begin{array}{l}\text { possible exemptions for } \\
\text { dental care (e.g. children, } \\
\text { pregnant or elderly patients, } \\
\text { emergency treatment) }\end{array}$ & no & -- & $\begin{array}{l}\text { individuals with } \\
\text { severe } \\
\text { illnesses or } \\
\text { other medical }\end{array}$ \\
\hline \multicolumn{7}{|l|}{ Financing of concessions } \\
\hline low-income individuals & $\begin{array}{l}\text { health insurance } \\
\text { institution }\end{array}$ & $\mathrm{n} / \mathrm{a}$ & gov't, health insurance fund & central gov't & $\begin{array}{l}\text { prefectures, } \\
\text { municipalities }\end{array}$ & $\mathrm{n} / \mathrm{a}$ \\
\hline benefit recipients & $\begin{array}{l}\text { UB \& SA: responsible } \\
\text { benefit office }\end{array}$ & $\mathrm{n} / \mathrm{a}$ & same as above & central gov't & central gov't & $\mathrm{n} / \mathrm{a}$ \\
\hline other & -- & $\mathrm{n} / \mathrm{a}$ & same as above & $\mathrm{n} / \mathrm{a}$ & $\mathrm{n} / \mathrm{a}$ & $\begin{array}{l}\text { national funds } \\
\text { and local gov't }\end{array}$ \\
\hline
\end{tabular}


Table 5 (continued). Health-related support for benefit recipients and low-income groups

\begin{tabular}{|c|c|c|c|c|c|}
\hline & Luxembourg & Netherlands & New Zealand & Norway & Poland \\
\hline Basic health coverage & $\begin{array}{c}\text { public } \\
\text { (insurance-based) }\end{array}$ & $\begin{array}{c}\text { public } \\
\text { (insurance-based) }\end{array}$ & $\begin{array}{c}\text { public } \\
\text { (tax-financed) }\end{array}$ & $\begin{array}{c}\text { public } \\
\text { (mainly tax-financed) }\end{array}$ & $\begin{array}{c}\text { public } \\
\text { (insurance-based) }\end{array}$ \\
\hline 'univeral' coverage & no & yes & yes & yes & no \\
\hline $\begin{array}{l}\text { derived rights for uninsured family } \\
\text { members }\end{array}$ & $\begin{array}{c}\text { yes } \\
\text { (at no cost) }\end{array}$ & no & $n / a$ & n/a & $\begin{array}{c}\text { yes } \\
\text { (at no cost) }\end{array}$ \\
\hline $\begin{array}{l}\text { potentially not covered } \\
\text { (e.g. groups who do not have to } \\
\text { contribute on a mandatory basis) }\end{array}$ & $\begin{array}{l}\text { irregular or } \\
\text { temporary workers } \\
\text { ( }<3 \text { months per } \\
\text { year })\end{array}$ & n/a & $\mathrm{n} / \mathrm{a}$ & $n / a$ & irregular or temporary w orkers \\
\hline \multicolumn{6}{|l|}{ Concessions 1: Insurance cost } \\
\hline low-income individuals & $\begin{array}{l}\text { contributions } \\
\text { subject to ceiling }\end{array}$ & $\begin{array}{c}\text { yes } \\
\text { (tax allow ance to cover } \\
\text { part of contribution) }\end{array}$ & $\mathrm{n} / \mathrm{a}$ & n/a & uninsured may apply for free healthcare \\
\hline benefit recipients & same as above & 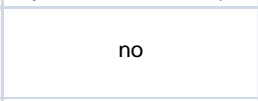 & $\mathrm{n} / \mathrm{a}$ & n/a & $\begin{array}{l}\text { exempt: registered unemployed; } \\
\text { recipients of SA, maternity/parental- } \\
\text { leave benefits }\end{array}$ \\
\hline other & same as above & no & $\mathrm{n} / \mathrm{a}$ & n/a & $\begin{array}{l}\text { (a) reduced contributions for some } \\
\text { pensioners; ( } b \text { ) eligible for free } \\
\text { healthcare: children, w omen during } \\
\text { pregnance and child delivery, refugees, } \\
\text { those w ith substance abuse issues }\end{array}$ \\
\hline $\begin{array}{l}\text { different coverage for those paying } \\
\text { preferential rates? }\end{array}$ & no & no & n/a & n/a & 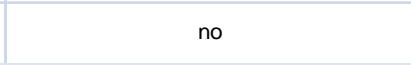 \\
\hline \multicolumn{6}{|l|}{ Concessions 2: Out-of-pocket } \\
\hline low-income individuals & no & no & $n / a$ & $\begin{array}{l}\text { co-payments subject to } \\
\text { annual ceiling }\end{array}$ & $\begin{array}{l}\text { co-payments for certain rehabilitation } \\
\text { measures depend on income }\end{array}$ \\
\hline benefit recipients & no & no & $\mathrm{n} / \mathrm{a}$ & same as above & SA: medication costs can be refunded \\
\hline other & no & no & $\begin{array}{l}\text { reduced rates for } \\
\text { individuals } w \text { ith } \\
\text { health problems, } \\
\text { from deprived areas }\end{array}$ & $\begin{array}{l}\text { co-payments subject to } \\
\text { annual ceiling; } \\
\text { exemptions for children, } \\
\text { certain types of patients }\end{array}$ & no \\
\hline \multicolumn{6}{|l|}{ Financing of concessions } \\
\hline low-income individuals & $\begin{array}{l}\text { health insurance } \\
\text { institution }\end{array}$ & central gov't & n/a & & central gov't \\
\hline benefit recipients & same as above & $\mathrm{n} / \mathrm{a}$ & $n / a$ & & central \& local gov't \\
\hline other & same as above & $\mathrm{n} / \mathrm{a}$ & central gov't & & central gov't \\
\hline
\end{tabular}


Table 5 (continued). Health-related support for benefit recipients and low-income groups

\begin{tabular}{|c|c|c|c|c|c|c|}
\hline & Portugal & Spain & Sweden & Switzerland & United Kingdom & United States \\
\hline Basic health coverage & $\begin{array}{c}\text { public } \\
\text { (tax-financed) }\end{array}$ & $\begin{array}{c}\text { public } \\
\text { (tax-financed) }\end{array}$ & $\begin{array}{c}\text { public } \\
\text { (tax-financed) }\end{array}$ & $\begin{array}{c}\text { private } \\
\text { (insurance-based) }\end{array}$ & $\begin{array}{c}\text { public } \\
\text { (tax-financed) }\end{array}$ & $\begin{array}{c}\text { private } \\
\text { (insurance-based) }\end{array}$ \\
\hline 'univeral' coverage & yes & yes & yes & yes & yes & no \\
\hline $\begin{array}{l}\text { derived rights for uninsured family } \\
\text { members }\end{array}$ & $\mathrm{n} / \mathrm{a}$ & $\mathrm{n} / \mathrm{a}$ & $\mathrm{n} / \mathrm{a}$ & no & $\mathrm{n} / \mathrm{a}$ & no \\
\hline $\begin{array}{l}\text { potentially not covered } \\
\text { (e.g. groups w ho do not have to } \\
\text { contribute on a mandatory basis) }\end{array}$ & $\mathrm{n} / \mathrm{a}$ & n/a & $\mathrm{n} / \mathrm{a}$ & $n / a$ & $\mathrm{n} / \mathrm{a}$ & $\begin{array}{l}\text { families without employment-based } \\
\text { insurance and not entitled to } \\
\text { targeted public programs (non- } \\
\text { coverage } 15 \% \text { overall) }\end{array}$ \\
\hline \multicolumn{7}{|l|}{ Concessions 1: Insurance cost } \\
\hline low -income individuals & $\mathrm{n} / \mathrm{a}$ & $\mathrm{n} / \mathrm{a}$ & $\mathrm{n} / \mathrm{a}$ & $\begin{array}{l}\text { reduced insurance } \\
\text { premia }\end{array}$ & $n / a$ & $\begin{array}{l}\text { Medicaid: Income+other conditions } \\
\text { vary by state. CHIPS: Higher income } \\
\text { limits for children's coverage. }\end{array}$ \\
\hline benefit recipients & $\mathrm{n} / \mathrm{a}$ & $\mathrm{n} / \mathrm{a}$ & $\mathrm{n} / \mathrm{a}$ & -- & $n / a$ & $\begin{array}{l}\text { unemployed have option to join } \\
\text { group-based insurance at reduced } \\
\text { rates; SSP: covered by Medicaid }\end{array}$ \\
\hline other & $\mathrm{n} / \mathrm{a}$ & $\mathrm{n} / \mathrm{a}$ & $\mathrm{n} / \mathrm{a}$ & -- & n/a & $\begin{array}{l}\text { blind, pregnant } w \text { omen with young } \\
\text { children covered by Medicaid }\end{array}$ \\
\hline $\begin{array}{l}\text { different coverage for those paying } \\
\text { preferential rates? }\end{array}$ & $\mathrm{n} / \mathrm{a}$ & $\mathrm{n} / \mathrm{a}$ & $\mathrm{n} / \mathrm{a}$ & no & $\mathrm{n} / \mathrm{a}$ & $\begin{array}{l}\text { emergency treatment must be pro- } \\
\text { vided; access difficult for uninsured }\end{array}$ \\
\hline \multicolumn{7}{|l|}{ Concessions 2: Out-of-pocket } \\
\hline low-income individuals & $\begin{array}{l}\text { exemptions for the } \\
\text { economically } \\
\text { disadvantaged }\end{array}$ & no & no & no & no & $\begin{array}{l}\text { rules about out-of-pocket payments } \\
\text { under Medicaid vary by state. }\end{array}$ \\
\hline benefit recipients & -- & no & SA & no & $\begin{array}{c}\text { UA; SA; in-w ork } \\
\text { benefit; child tax credit }\end{array}$ & same as above \\
\hline other & $\begin{array}{c}\text { exemptions for } \\
\text { pregnant w omen, } \\
\text { children, low -income } \\
\text { pensioners }\end{array}$ & no & no & -- & $\begin{array}{l}\text { individuals } w \text { ith special } \\
\text { medical conditions, } \\
\text { pregnant w omen, } \\
\text { recent mothers }\end{array}$ & same as above \\
\hline \multicolumn{7}{|l|}{ Financing of concessions } \\
\hline low-income individuals & central gov't & n/a & $\mathrm{n} / \mathrm{a}$ & $\begin{array}{l}\text { federal gov't, } \\
\text { cantons }\end{array}$ & $\mathrm{n} / \mathrm{a}$ & $\begin{array}{l}\text { Medic aid: state and federal gov't; } \\
\text { CHIPS: federal }\end{array}$ \\
\hline benefit recipients & $\mathrm{n} / \mathrm{a}$ & n/a & -- & -- & central gov't & Medicaid: state and federal gov't \\
\hline other & central gov't & $\mathrm{n} / \mathrm{a}$ & $\mathrm{n} / \mathrm{a}$ & -- & $n / a$ & same as above \\
\hline
\end{tabular}

Notes: Countries are not shown if no responses were received at the time of witing. 'n/a': not applicable; '-': information not received or incomplete; 'UB' : unemployment benefits; 'UA': unemployment assistance; 'SA': social assistance. Source: Country responses to OECD questionnaire on health-related support for benefit recipients. 


\section{4. $\quad$ Recipients}

Data on the number of people covered by minimum-income benefits in OECD countries are not currently available on a comprehensive basis. ${ }^{17}$ One source that does show recipient numbers for 'noncategorical' social assistance as well as lone-parent benefits for a subset of OECD countries is Carcillo and Grubb (2006), who compiled information from a range of available administrative data sources (OECD, 2003a, contains further data and a detailed discussion of methods and concepts). For the purpose of that study, it was necessary to avoid double-counting benefit recipients who receive multiple benefits at the same time (or at different times during the same year). It therefore made sense to categorise recipients according to the main out-of-work benefit they received. As a result, those receiving both social assistance and unemployment benefits would normally not show up in the social assistance recipient totals. Perhaps more importantly, the administrative data relate to claimants while minimum-income benefits are targeted towards families. For the purpose of analysing the redistributive scope of minimum-income benefits, one would typically be less interested in claimant counts and more in the number of individuals who live in a beneficiary household.

With these limitations in mind, the data provided by Carcillo and Grubb show that the shares of working-age individuals receiving benefits of last resort are modest, mostly between 2 to 4 percent but below 2 percent in a few countries. The policy significance of these benefits is, however, greater than these figures suggest. As highlighted above, the statistics only count one adult per family as a recipient; the number of individuals whose families are supported by minimum-income benefits is higher. More importantly, behavioural requirements and other barriers (such as the perceived burden of filing an application) in effect exclude some of those who would otherwise be entitled. Studies on benefit take-up regularly find very high non-take-up rates for means-tested benefits in the order of $40 \%$ or more, indicating that the deterrent effect of the various barriers combined is indeed significant (Hernanz et al., 2004; Bargain et al., 2009). Finally, because out-of-work benefits affect both income levels and work incentives, their generosity and structure has implications for both recipients and non-recipients. For instance, to the extent that they achieve their objectives, work-related requirements reduce benefit dependency by strengthening labour-market attachment.

Considering these effects in combination, one can expect low-income groups potentially targeted by social assistance benefits to be much more sizable than indicated by the above recipiency statistics. This is confirmed by calculations combining survey data with a detailed representation of benefit entitlement rules. For instance, in the late 1990s, 8 percent of working-age adults in the US lived in households whose income position would have made them eligible for social assistance-type cash transfers at some point during the year (i.e., without counting near-cash benefits such as Food Stamps). In Germany, the corresponding figure is as high as 14 percent. ${ }^{18}$ Over a longer time-period, the proportion of individuals who experience at least one spell where family incomes fall below minimum-income thresholds will be even higher.

17. Since 'activating' policy approaches seek to encourage labour market attachment and reduce benefit dependency, one critical outcome of such policies is the pattern of transitions into and out of benefit receipt. Even more so than in the case of comparable aggregate beneficiary statistics, there is currently very little data on who moves onto minimum-income benefits, the typical duration of their benefit receipt, and whether those no longer drawing on income support quickly return to the benefit rolls or remain off benefit for longer periods. A recent study by Cappellari and Jenkins (2008) provides important insights on these dynamic aspects using household panel data for the United Kingdom. They also summarise methodological issues and present a method that could be used to perform similar analyses for other countries where goodquality household panel data are available.

18. The Secretariat has commissioned these calculations as part of a project entitled "Welfare Implications of Social Protection”. See Dang et al. (2006). They are based on the assumptions of $100 \%$ benefit-takeup and full compliance with activity requirements and related eligibility conditions. 
In view of the poverty alleviation objectives of minimum-income benefits, and the findings of high non-take-up rates, an important perspective of recipiency statistics is the fraction of poor people that these benefits reach. As an illustration of orders of magnitude, Figure 4 below combines administrative data on benefit recipients for two Nordic countries with survey-based totals of the number of income-poor households. The resulting proportions are "pseudo coverage rates" in the sense that they express the relative sizes of two groups that may only be partially overlapping (a number of non-poor households may receive minimum-income benefits). Two observations stand out. First, it is clear that a large number of income-poor households do not receive minimum-income support even in countries where benefit levels are relatively generous. Since benefit levels (see Figure 2 above) are close to the poverty cut-off in both countries, the principal driving factors are likely to be non-take-up as well as non-income characteristics that may make some of the income-poor households ineligible (notably assets or non-compliance with jobsearch or other activity requirements).

Figure 4. Number of households receiving minimum-income benefits relative to income-poor households

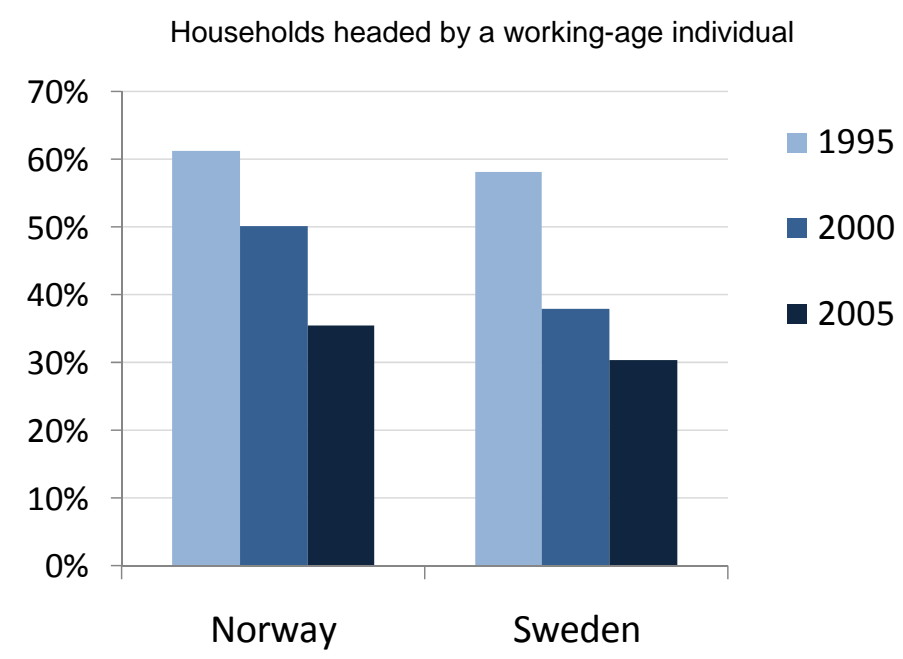

Sources: Author's calculations based on the following sources. Benefit recipiency data: update of the data series described in Carcillo and Grubb (2006); Number of poor households: OECD income distribution database.

A second striking pattern of the "pseudo" coverage rates is the extent of their variability over time. Given uncommonly high unemployment rates in Nordic countries during the mid-nineties, this illustrates the counter-cyclical role of minimum-income safety-nets even in countries where unemployment benefits generosity and durations are above the OECD average. It also suggests that demand for minimum-income support will grow significantly and that safety nets could be severely tested during the current economic downturn. But the downward trend also highlights the important role of "mutual obligations" policies and other measures aiming to reduce dependency on last-resort benefits: While labour markets weakened between 2000 and 2005 in both Norway and Sweden, the number of minimum-income benefit claimants continued to decline (both in absolute terms and as a proportion of poor households).

\section{Responsibilities of benefit recipients}

\subsection{Why "rights and responsibilities"?}

The large numbers of individuals potentially entitled to receiving minimum-income benefits highlight the importance of an appropriate balance between encouraging self-sufficiency and providing assistance for those who cannot support themselves. A simple income guarantee with no conditions attached could 
result in very high rates of benefit dependency and the possibility of a downward spiral of weak work incentives and declining employability. Depending on the generosity of support, it could also be very costly for the public finances. Budgetary pressures are one likely reason why governments have increasingly considered a more work-oriented approach to minimum-income benefits. A welfare-to-work approach may also make income support for low-income groups politically more acceptable.

Another reason is that, in most countries, last-resort benefit payments alone simply do not provide enough income to ensure effective protection from income poverty. Where more generous benefit payments are economically or politically infeasible, there is therefore a strong case for structuring financial support in a way that enables and encourages benefit recipients to seek income from employment. There is convincing evidence that welfare-to-work policies can be effective at increasing employment levels among the groups most likely to draw on minimum-income benefits. Several initiatives that have targeted safetynet benefit recipients show that substantial shares of them do respond to these measures: if the conditions are right, they will work and reduce their reliance on public support.

However, the large numbers of individuals "potentially entitled" to minimum-income benefits could also indicate that many may simply be unable to earn incomes above the levels that these benefits provide. There is therefore a real danger that severe behavioural requirements, strictly enforced, would lead to much higher poverty risks. For instance, there is evidence for the US that, while many lone parents have left welfare and found work, as many as $25 \%$ of them are neither employed nor receiving welfare benefits. ${ }^{19}$ Even if strict eligibility conditions are successful at increasing employment and reducing poverty rates overall, families excluded from the benefit can face much deeper poverty, which is a concern in itself and can also lead to political backlash. In addition to the direct income effect, overly-strict eligibility conditions and rigorous gate-keeping can also have negative consequences for the effectiveness of employmentoriented policies: those excluded from benefit payments may de facto have no or incomplete access to jobsearch assistance and other counselling or re-integration measures; by dropping out of the system, they are then no longer "reachable". Finally, there have been concerns about the appropriateness of an indiscriminate pursuance of the self-sufficiency objective itself. This issue is, for instance, central to the question of whether and for how long lone parents should be exempt from activity requirements and whether such requirements are appropriate for individuals facing severe social difficulties. It is possible that "families who are in turmoil or who cannot organize their lives sufficiently to comply with the rules are the same ones who are forced off welfare, and are likely to be worse off as a result." (Moffitt, 2008, p. 22).

Compared with unemployment benefit recipients, those entitled to lower-tier income support face greater employment difficulties on average. Training, public sector job creation programmes and other active labour market programmes (ALMPs) can help address some of these difficulties. But existing research shows that targeting is key and that overall success rates might be low especially for those facing substantial or multiple employment barriers. In terms of beneficiaries' responsibilities, the notion that public support ought to be linked to behavioural requirements is more controversial when applied to individuals who are faced with multiple or particularly serious challenges to finding paid work or who see little gain from substituting earnings for state transfers.

In spite of these challenges, minimum safety-net benefits are of particular significance in this debate. First, since there is generally little other public support to fall back on, too strict an application of behavioural eligibility conditions could result in extremely low incomes for those excluded from benefit payments. Concerns about those potentially 'falling through the cracks' become more acute if potential beneficiaries fail to live up to their responsibilities, not because they are unwilling but because they are unable to comply.

19. See Blank (2007). 
Second, there are important links between benefits of last resort and other, higher-tier, support systems. As entitlements to primary out-of-work benefits such as unemployment insurance payments are tied more visibly to job-search and availability criteria, lower-tier assistance benefits are likely to play a stronger role as a fall-back option. Whether or not such benefit substitution is intended, there is a clear need to co-ordinate activation and re-integration policies between the different benefit layers (as noted above, some English-speaking countries operate only one main layer of income support, although even then, other benefits may, under specific circumstances, be granted to individuals not entitled to the primary transfer).

Finally, the group of low-income individuals relying on benefits of last resort is very heterogeneous. It includes those with low-paid, irregular or undeclared employment, the long-term unemployed, individuals who have never worked, those with disabilities, health problems or substance abuse issues, those requiring support because of difficult family or social circumstances (including lone parents, migrants and victims of family violence), homeless people, those released from a penal institution, and those facing any combination of the above. Any strategy to encourage self-sufficiency among such a diverse client group is likely to be both complex and demanding. The challenge is to channel the right type of support to the right people while responding to a broad range of different circumstances and needs.

\subsection{Targeting: The right mix of rights and responsibilities, for the right people, at the right time}

In essence, the attraction of a 'rights and responsibilities' approach is that it potentially increases employment while improving the targeting of minimum safety nets. By imposing more demanding behavioural conditions for benefit receipt, it makes work relatively more attractive and limits opportunities for benefit claims that might be considered "undeserving" (e.g. those with incomes from undeclared employment or a strong preference for leisure). At the same time, work-related behavioural requirements seek to improve employability. Both effects would in theory reduce the number of beneficiaries, and this effect can be further strengthened by providing job-search assistance and other employment-oriented support. With a reduced number of beneficiaries and stronger work incentives, more adequate support is feasible for those who need it most.

But a second concern of targeting efficiency is that those unable to achieve self-sufficiency should not be left without sufficient support. As discussed, the downside of stringent requirements is that they can make support inaccessible for some. Sanctioning those unable to comply reduces benefit expenditures but clearly makes little sense from a redistribution point of view. Policymakers would likely be concerned if sanctions for failing to comply with work requirements are frequently applied to individuals who are in fact not ready for work. Evidence suggesting such a pattern in the US shows that this is a real danger (Pavetti et al., 2003). For instance, decisions about sanctions can be affected by administrative error with potentially grave consequences for sanctioned families. In this context, a transparent and efficient appeals process, while costly to operate, is an important element of an effective benefit administration. By providing some evidence on the frequency of unjustified sanctions, it can also help uncover structural problems, such as insufficient resources to properly account for clients' circumstances. Children, who are directly affected by benefit cuts but can do little to avoid them, are a group of particular concern (although many countries implicitly recognise this by protecting child-related benefit amounts from sanctions, this does not protect children from deteriorating living standards caused by cuts in non-child-related benefit components).

This issue can in principle be tackled from two sides. First, behavioural obligations, and the sanctions that back them up, should take account of individual circumstances. Second, those who are not job-ready should be given an opportunity to participate in programmes aiming to overcome employment barriers. Participation in these support programmes can be made mandatory. Other work-related support measures 
should seek to address barriers that are not primarily related to the employability of the individual (e.g. childcare for parents).

Targeting is therefore key on both ends of the mutual obligations. In view of the wide heterogeneity of the group of minimum-income benefit recipients, implementing effective targeting mechanisms presents a major challenge, however.

Providing customised packages of client support and obligations requires detailed information and adequate staff and other resources. Statistical profiling approaches can help exploit available information but they are no substitute for intensive and face-to-face contact with claimants, especially in the more difficult cases where clients face severe or multiple barriers to social or economic participation. This type of interaction requires a significant commitment of staff resources and, hence, public expenditures to provide the necessary service capacity. One way to make service delivery potentially more responsive to claimants' circumstances is to decentralise service delivery and possibly also administrative responsibilities for social assistance benefit payments. The funding mechanisms themselves can also have a direct effect on how support is targeted in practice. For instance, a rights-based entitlement to financial support is likely to put less pressure on case workers to deny benefit payments than a 'queuing' system whereby support is subject to availability of funds (as was the case in Poland prior to a 2004 reform, and is the case for those claiming TANF support in the US, although prior to the current recession, funding limits have generally been non-binding due to declining caseloads). Some of these institutional issues will be taken up below.

Beyond matching claimants with appropriate interventions, targeting also has an important time dimension. Clearly, job-search assistance, labour market re-integration programmes and work requirements are most effective when suitably sequenced. This may also mean employing different types of requirements and support measures at the same time. For instance, one would expect synergies of combining job-search obligations with employment counselling. Mandating certain activities can however be counter-productive if they compromise the individual's own initiative to escape benefit dependency. For instance, job-training or counselling may leave too little time for formal and informal job search (the socalled 'lock-in' effect of mandatory participation in ALMPs). Yet, an overly aggressive push for work that does not allow for a sufficiently careful job-search may reduce the quality of job matches and result in less stable employment.

Some of these timing issues have received considerable attention in the debate on activating recipients of first-tier unemployment benefits but have been shown to be of less practical relevance for the more disadvantaged recipients of social assistance. A likely reason is that the nature of the employment barriers facing the latter group is such that they are on average less likely to succeed at independent job-search activities. But due to the heterogeneity of the group of welfare recipients, timing issues can be expected to be significant nonetheless for some sub-groups. For young welfare recipients, the existing evidence suggests that work requirements should start at a very early stage as lacking work experience seems to be the main barrier to employment (Martin and Grubb, 2001). As noted, there are also important, and controversial, timing issues for lone parents as compulsory work or participation in labour market programmes means that they can spend less time with their (possibly young) children.

\subsection{An illustration of benefit recipients' obligations}

Using responses to a recent questionnaire on this topic, Table 6 summarises the main behavioural requirements, as well as the sanctions that may be used to enforce them. Behavioural requirements vary both across countries and across programmes within countries. Importantly, the table relates mostly to legal provisions (and sometimes administrative guidelines). Information about the implementation of these provisions in practice is currently patchy, although an on-going review of activation policies has resulted in 
detailed information for a number of countries (see footnote 1). Such information would be particularly relevant when assessing the relevance of different requirements in countries where programme implementation is highly decentralised.

Behavioural requirements tend to be well defined in countries where the main social assistance scheme is at the same time the principal benefit for all or many registered unemployed (e.g. Australia, New Zealand, United Kingdom). In most other countries for which information has been received, provisions for behavioural requirements appear to be less comprehensive.

A requirement to register with the public employment service (PES) indicates that gaining or restoring self-sufficiency is an objective, but it does not necessarily mean that explicit job-search requirements exist or that they are strictly enforced. A lack of explicit standards for independent job search in most countries suggests an underlying presumption of low success rates among welfare benefit recipients at informal job search, and, correspondingly, that the likelihood of successful labour market integration could be increased by using a more structured and formal process.

Specific job-suitability criteria (relating, e.g., to working hours and conditions, pay, location, or type of activity) exist in the Czech Republic, Germany, Hungary, New Zealand, the Slovak Republic and Spain. In these cases, jobs that are offered but do not meet specified criteria can be refused without triggering a benefit sanction. In a number of other countries, suitability criteria exist but are non-explicit or are largely subject to case-worker discretion.

In addition to the obligation of accepting or applying for available regular jobs, requirements can also extend to accepting a slot in a labour market programme, which may include work-like activities in the public or non-profit sector aiming, for instance, at strengthening basic job-related skills. They can also reflect a strict mutual obligations framework in which benefit recipients are required to work in return for receiving benefits ("workfare") with no or little additional pay (e.g., Work for the Dole in Australia or the so-called "1-euro jobs" in Germany).

Reflecting the fact that minimum-income benefits are family-based payments, several countries extend behavioural requirements to family members other than the benefit claimant ("Requirements extend to other Family Members" in Table 6). A number of countries have recently tightened work-availability criteria for the partners of benefit recipients (e.g., Germany, United Kingdom, although responses on the relevant item are missing for several countries), although exemptions are usually in place for partners with caring responsibilities and for family members who follow a recognised education programme.

One-off or recurring intensive client interviews are used in all countries where information on this item was provided. Intensive interviews combine aspects of both behavioural requirements (there is an obligation to attend) and reintegration services mentioned in the previous section (interviews can be opportunities for providing job-search guidance or pointing out assistance to which clients are entitled). Either way, interviews are an essential tool for determining client needs, matching them with available reintegration services and assessing progress towards reintegration objectives. An initial intensive interview can be the basis for agreeing an individual 'action plan', a contract-type document that explicitly defines client rights and responsibilities and sets out measures intended to address the client's difficulties, as well as reintegration objectives. In subsequent interview sessions, the effectiveness of interventions and reintegration measures can be assessed against these objectives, with confirmation or adaptations of the action plan as needed. In addition to their role in customising and managing the integration process, individual action plans also serve as a motivational device that provides clients with a set of clear personal objectives to work towards. 
Most, but not all, countries provide for the possibility of sanctions for welfare-benefit recipients (benefit reductions, suspensions or stops). The scope and structure of sanctions can be a reflection of their underlying objective. For instance, sanctions may be partial or temporary if the aim is to correct noncompliant behaviour, while more severe sanctions might be expected if the objective is to generally tighten access to benefits or to reduce beneficiary numbers. Questionnaire responses indicate that in the case of minor infringements, such as failing to provide information requested by the benefit agency, some countries only issue warnings (Australia, Japan). In most other countries that provided responses, minor cases of non-compliance trigger a partial benefit reduction. New Zealand, Spain, the United Kingdom and the United States appear to suspend benefits until compliance is re-established, or for a certain minimum period. In most countries, there is a possibility of suspending benefit payments for more severe cases of non-compliance (e.g. failing to attend a scheduled interview) or repeated infringements. Cases of major non-compliance (such as failing to accept a job offer or non-participation in labour market programmes) tend to make an individual ineligible for the benefit, although benefits are sometimes suspended for a defined period of time, rather than stopped entirely.

In practice, concerns over income adequacy may make sanctions partial, even in cases of major noncompliance. For instance, reductions or suspensions may only apply to those portions of the benefit that relate to the non-complying individual while amounts intended to cover the needs of spouses and children may be unaffected (e.g., in Germany). In some countries, formal rules that seek to protect sanctioned individuals and their families from incomes below a given subsistence level can further reduce the scope of benefit sanctions (e.g., Czech Republic, Norway, Poland). These latter three countries, as well as the Slovak Republic operate interesting variants of a limited sanctions scheme that place somewhat more emphasis on economic incentives than on benefit reductions (see notes to Table 6 for sources). While social assistance entitlements at the subsistence level in the Czech Republic and the Slovak Republic are not subject to explicit behavioural requirements, benefit clients receive a so-called "activation allowance" for as long as they are registered with the PES and satisfy relevant behavioural requirements. In 2007, Norway has introduced a "qualification benefit" which entitles participants in one-year qualification programmes to higher benefit payments which can also be combined with some employment income. Similarly, since 2005, social assistance recipients in Poland who are considered employable in principle have the option of signing on to occupational reintegration programmes with a Social Integration Centre. While participating in these programmes, and subject to meeting relevant behavioural requirements, they receive an "integration allowance" on top of their social assistance payments.

In general, information on the tightness of benefit sanction regimes is difficult to compare across countries based on formal rules which provide little indication of how they are applied in practice. In fact, several countries state that sanctions are "possible" or that the details "vary" depending on circumstances, region or benefit office (Austria, Netherlands, Norway, Poland, Sweden, United States). Other countries have provided no information on sanctions. Detailed administrative statistics on benefit sanctions can facilitate more objective country comparisons. However, breakdowns needed for informative analyses (e.g., by type of infringement) are often not available, although the data situation tends to be better in countries where minimum-income benefits are also the main unemployment benefits (see e.g. Grubb et al., 2009, Section 4.4). 
Table 6. Behavioural requirements and benefit sanctions, 2007 or as indicated

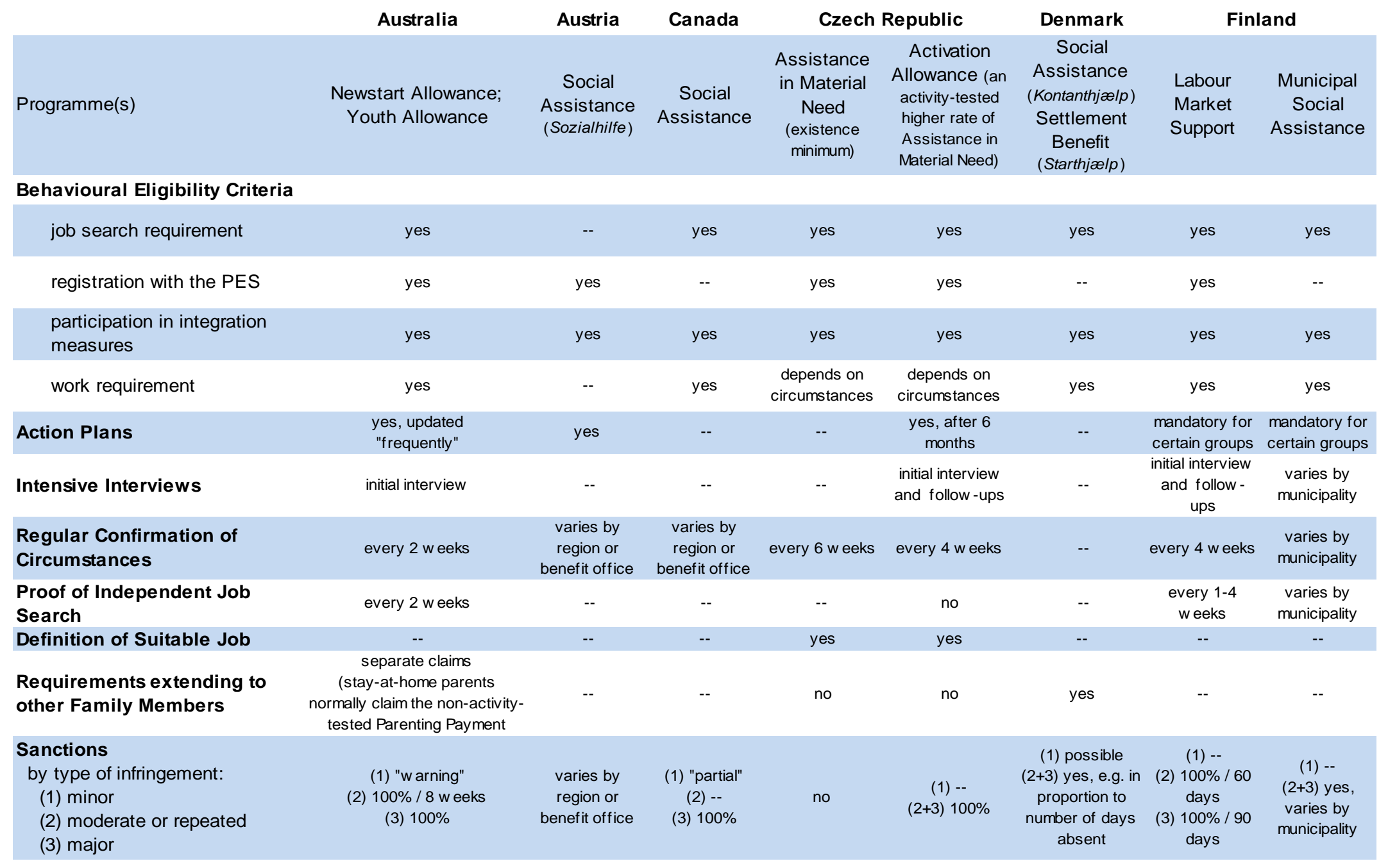


Table 6 (continued). Behavioural requirements and benefit sanctions, 2007 or as indicated

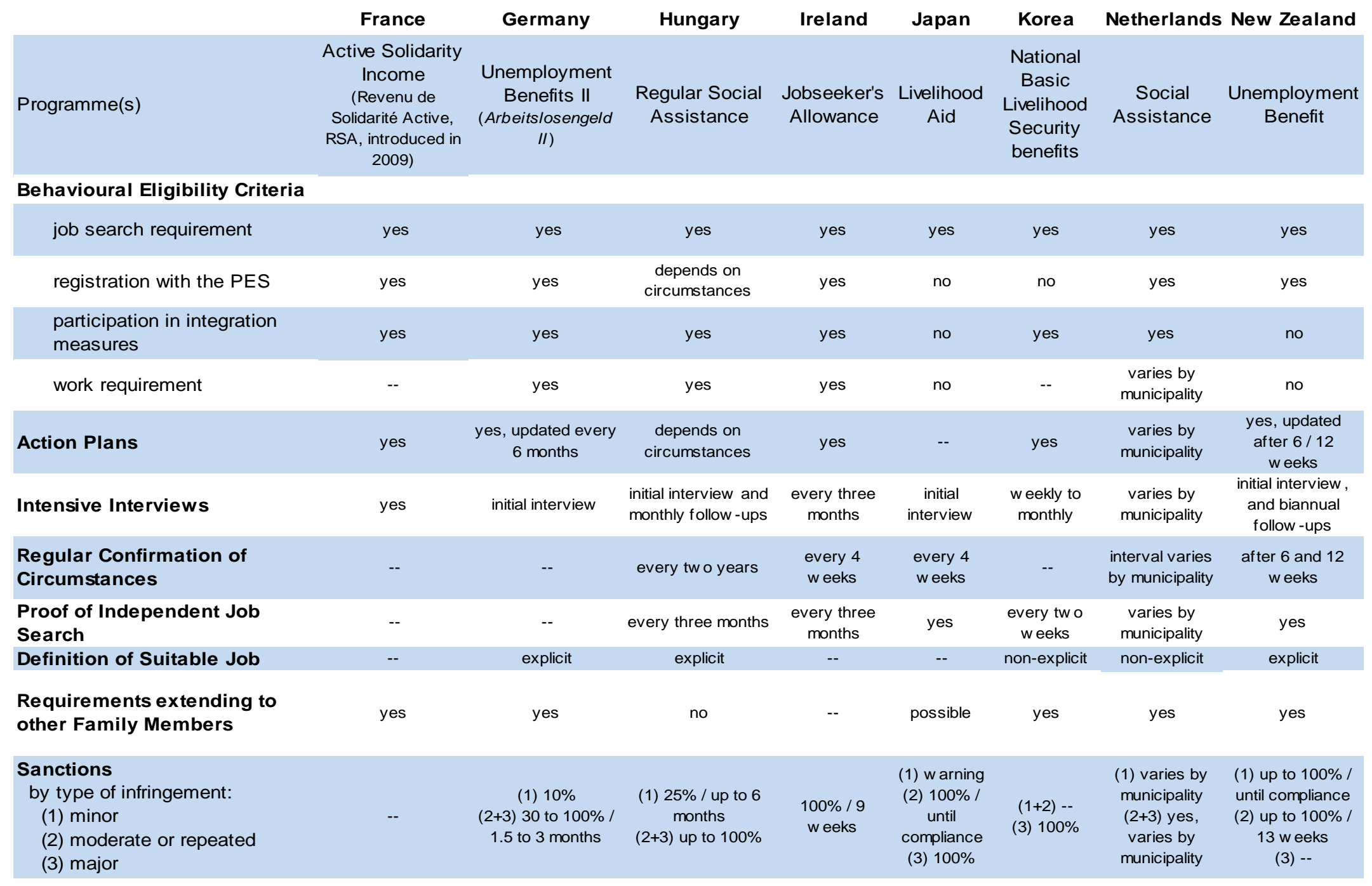


Table 6 (continued). Behavioural requirements and benefit sanctions, 2007 or as indicated

\begin{tabular}{|c|c|c|c|c|c|c|}
\hline & \multicolumn{2}{|c|}{ Norway } & \multicolumn{2}{|l|}{ Poland } & \multirow{2}{*}{$\begin{array}{l}\text { Portugal } \\
\text { Social } \\
\text { Integration } \\
\text { Income }\end{array}$} & \multirow[b]{2}{*}{$\begin{array}{l}\text { Minimum Income } \\
\text { for Insertion } \\
\text { (Renta Mínima de } \\
\text { Inserción) }\end{array}$} \\
\hline Programme(s) & $\begin{array}{l}\text { Social Economic } \\
\text { Assistance }\end{array}$ & $\begin{array}{l}\text { Qualification Benefit } \\
\text { (an activity-tested } \\
\text { supplement to the main } \\
\text { benefit for participants } \\
\text { in a Qualification } \\
\text { Programme) }\end{array}$ & $\begin{array}{l}\text { temporary benefit } \\
\text { (zasitek okresowy) }\end{array}$ & $\begin{array}{l}\text { Integration Allowance } \\
\text { (an activity-tested } \\
\text { supplement to the main } \\
\text { benefit for participants in } \\
\text { Social Integration } \\
\text { Centres) }\end{array}$ & & \\
\hline \multicolumn{7}{|l|}{ Behavioural Eligibility Criteria } \\
\hline job search requirement & $\begin{array}{l}\text { depends on } \\
\text { circumstances }\end{array}$ & $\begin{array}{l}\text { depends on } \\
\text { circumstances }\end{array}$ & $\begin{array}{l}\text { depends on circumstances } \\
\text { (social activation can be priority) }\end{array}$ & no & -- & yes \\
\hline registration with the PES & no & no & $\begin{array}{l}\text { depends on circumstances } \\
\text { (social activation can be priority) }\end{array}$ & no & yes & yes \\
\hline $\begin{array}{l}\text { participation in integration } \\
\text { measures }\end{array}$ & yes & yes & no & yes & yes & yes \\
\hline work requirement & no & $\begin{array}{l}\text { depends on } \\
\text { circumstances }\end{array}$ & no & yes & -- & yes \\
\hline Action Plans & yes & yes & yes (but not not mandatory) & yes & yes & yes \\
\hline $\begin{array}{l}\text { Regular Confirmation of } \\
\text { Circumstances }\end{array}$ & varies by municipality & varies by municipality & every three months & -- & -- & every 3 months \\
\hline $\begin{array}{l}\text { Proof of Independent Job } \\
\text { Search }\end{array}$ & varies by municipality & -- & depends on circumstances & no & -- & -- \\
\hline Definition of Suitable Job & -- & -- & -- & -- & -- & explicit \\
\hline $\begin{array}{l}\text { Requirements extending to } \\
\text { other Family Members }\end{array}$ & separate claims & separate claims & no & -- & yes & no \\
\hline $\begin{array}{l}\text { Sanctions } \\
\text { by type of infringement: } \\
\text { (1) minor } \\
\text { (2) moderate or repeated } \\
\text { (3) major }\end{array}$ & $\begin{array}{c}\text { (1) rare } \\
(2+3) \text { subject to } \\
\text { income not falling } \\
\text { below substistence } \\
\text { level }\end{array}$ & $\begin{array}{c}(1)-- \\
(2+3) 100 \%\end{array}$ & $\begin{array}{l}\text { varies by municipality, } \\
\text { legal requirement to consider } \\
\text { effect on incomes of } \\
\text { dependents. }\end{array}$ & $\begin{array}{l}(1)-- \\
(2+3) 5 \% \text { for each } \\
\text { unjustified absence; } \\
100 \% \text { if } 3 \text { or more } \\
\text { absences / } 1 \text { month }\end{array}$ & -- & $\begin{array}{c}\text { (1) } 100 \% / 4 \text { w eeks } \\
\text { (2) } 100 \% / 3 \text { to } 6 \\
\text { months } \\
\text { (3) } 100 \% / 3 \text { months to } \\
\text { indefinite }\end{array}$ \\
\hline
\end{tabular}


Table 6 (continued). Behavioural requirements and benefit sanctions, 2007 or as indicated

\begin{tabular}{|c|c|c|c|c|c|c|c|}
\hline & \multicolumn{2}{|c|}{ Slovak Republic } & Sweden & Switzerland & United Kingdom & \multicolumn{2}{|c|}{ United States } \\
\hline Programme(s) & $\begin{array}{c}\text { Benefits in } \\
\text { Material Need }\end{array}$ & $\begin{array}{l}\text { Activation } \\
\text { Allowance (an } \\
\text { activity-tested } \\
\text { supplement to } \\
\text { the main benefit) }\end{array}$ & $\begin{array}{l}\text { Social Welfare } \\
\text { Allowance }\end{array}$ & $\begin{array}{c}\text { Social } \\
\text { Assistance }\end{array}$ & $\begin{array}{l}\text { Jobseeker's } \\
\text { Allowance } \\
\text { (Income-based) }\end{array}$ & Food Stamps & $\begin{array}{c}\text { Temporary } \\
\text { Assistance for } \\
\text { Needy } \\
\text { Families (TANF) }\end{array}$ \\
\hline \multicolumn{8}{|l|}{ Behavioural Eligibility Criteria } \\
\hline job search requirement & no & yes & yes & yes & yes & yes & yes \\
\hline registration with the PES & no & yes & yes & $\begin{array}{l}\text { varies by canton or } \\
\text { benefit office }\end{array}$ & yes & yes & $\begin{array}{l}\text { varies by state or } \\
\text { benefit office }\end{array}$ \\
\hline $\begin{array}{l}\text { participation in integration } \\
\text { measures }\end{array}$ & no & yes & yes & yes & yes & yes & $\begin{array}{c}\text { varies by state or } \\
\text { benefit office }{ }^{5}\end{array}$ \\
\hline work requirement & no & yes & yes & $\begin{array}{l}\text { varies by canton or } \\
\text { benefit office }\end{array}$ & yes & yes & $\begin{array}{c}\text { varies by state or } \\
\text { benefit office }\end{array}$ \\
\hline Action Plans & no & $\begin{array}{l}\text { yes, within } 6 \\
\text { months }\end{array}$ & $\begin{array}{l}\text { varies by } \\
\text { municipality }\end{array}$ & -- & yes, updated quarterly & -- & -- \\
\hline Intensive Interviews & -- & -- & $\begin{array}{l}\text { varies by } \\
\text { municipality }\end{array}$ & -- & $\begin{array}{l}\text { initial interview, } \\
\text { quarterly follow -ups }\end{array}$ & -- & -- \\
\hline $\begin{array}{l}\text { Regular Confirmation of } \\
\text { Circumstances }\end{array}$ & -- & $\begin{array}{l}\text { every } 1 \text { to } 4 \\
\text { weeks }\end{array}$ & every 4 w eeks & -- & every 2 w eeks & $\begin{array}{l}\text { varies by state or } \\
\text { benefit office }\end{array}$ & -- \\
\hline $\begin{array}{l}\text { Proof of Independent Job } \\
\text { Search }\end{array}$ & no & $\begin{array}{l}\text { yes, frequency } \\
\text { varies locally }\end{array}$ & -- & -- & every 2 w eeks & if requested & -- \\
\hline Definition of Suitable Job & no & explicit & -- & -- & -- & -- & -- \\
\hline $\begin{array}{l}\text { Requirements extending to } \\
\text { other Family Members }\end{array}$ & no & yes & -- & -- & $\begin{array}{l}\text { yes, but depends on } \\
\text { circumstances (e.g. } \\
\text { recognised caring } \\
\text { responsibilities) }\end{array}$ & yes & -- \\
\hline $\begin{array}{l}\text { Sanctions } \\
\text { by type of infringement: } \\
\text { (1) minor } \\
\text { (2) moderate or repeated } \\
\text { (3) major }\end{array}$ & no & $\begin{array}{l}\text { (1+2) no } \\
\text { (3) } 100 \% / 12 \\
\text { months }\end{array}$ & $\begin{array}{l}\text { varies by } \\
\text { municipality }\end{array}$ & $\begin{array}{l}\text {-- / maximum } \\
\text { duration } 12 \text { months }\end{array}$ & $\begin{array}{c}\text { (1) } 100 \% / 2 \text { w eeks } \\
\text { (2+3) } 100 \% / \text { up to } \\
26 \text { w eeks }\end{array}$ & $\begin{array}{c}\text { (1) } 100 \% / \geq 1-3 \\
\text { months } \\
\text { (2) } 100 \% / \geq 3-6 \\
\text { months } \\
\text { (3) } 100 \% / \geq 6 \text { months }\end{array}$ & $\begin{array}{l}\text { varies by state or } \\
\text { benefit office }^{5}\end{array}$ \\
\hline
\end{tabular}


Notes: 'n/a': not applicable; '--': information not received or incomplete. Information is for 2007 or as indicated in the sources. Information relates to prime-age benefit recipients. Young adults often face more demanding requirements and stricter sanctions, while groups with particular work barriers (such as caring responsibilities, see Table 7 below) may be exempt from requirements altogether. 2. Some information is available from fact-finding mission (see sources). 3. Sanction rates lower for certain client groups. 4 . Information refers to activation allowance. No similar provisions exist for the basic benefit. 5. The Urban Institute Welfare Rules Database (http://anfdata.urban.org/wrd) presents information by state.

Sources: OECD questionnaire on approaches to the activation of social assistance recipients. Canada: Social Assistance Statistical Report: 2005, published by the Federal-ProvincialTerritorial (FPT) Directors of Income Support (2006), available online: http://www.hrsdc.gc.ca/en/cs/sp/sdc/socpol/page00.shtml. Denmark: MISSOC Tables 2007 published by the European Commission (2007), available online: http://ec.europa.eu/employment social/social protection/missoc tables en.htm. Switzerland: non-binding guidelines published by the Swiss Conference of Institutions for Social Action; Conference Suisse des Institutions d'Action Sociale (2005): Aide sociale: concepts et normes de calcul (http://www.skos.ch/store/pdf f/richtlinien/richtlinien/RL franz 2008.pdf). Czech Republic: Kalužná (2008a). Poland: Kalužná (2009). Slovak Republic: Kalužná (2008b). Information for Finland and Ireland was collected by the Secretariat during fact-finding missions on active labour market policies in January 2008 and November 2007 respectively. 


\section{Activity requirements for lone parents}

Behavioural requirements do not apply uniformly across all groups of benefit recipients. For instance, lone parents are frequently excluded from certain requirements or their obligations are modified to account for the particular circumstances facing these families. To illustrate the enormous variation in behavioural requirements for lone parents across countries, Table 7 reproduces information on work requirements collected in the context of previous OECD work. Lone-parent benefits are generally designed to enable the parent to remain the principal care-giver until the youngest child reaches a certain age. During this time, job-search requirements may be minimal and participation in job-search assistance or other reintegration measures may be on a voluntary basis. Once the upper age limit is reached, lone parents may be automatically transferred to the main unemployment benefit (and have to comply with the requirements as relevant, e.g., in Australia). Alternatively, there can be an expectation that most lone parents are in principle able to find work (e.g., in the Nordic countries). Belgium and Japan have no formal guidelines and leave decisions to case-worker discretion. Benefits paid to lone parents in Portugal and Spain are not subject to a work test.

Table 7. Work tests for lone parents, selected countries, around 2006

\begin{tabular}{|c|c|c|}
\hline \multirow[t]{2}{*}{ No work test } & \multicolumn{2}{|r|}{ Work test } \\
\hline & $\begin{array}{l}\text { Independent of } \\
\text { child age }\end{array}$ & $\begin{array}{l}\text { Dependent on child age } \\
\text { (age limit in years) }\end{array}$ \\
\hline $\begin{array}{l}\text { Portugal } \\
\text { Spain }\end{array}$ & $\begin{array}{c}\text { Belgium }^{1} \\
\text { (Discretion) } \\
\text { Denmark } \\
\text { (subject to } \\
\text { childcare) } \\
\text { Finland } \\
\text { Japan }^{5} \\
\text { (Discretion) }^{\text {Sweden }}\end{array}$ & 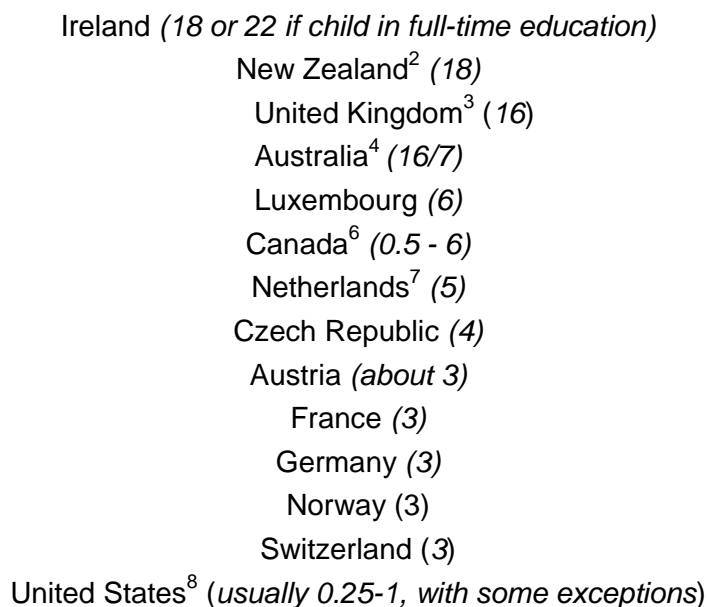 \\
\hline
\end{tabular}

General note: In many countries there is a general system of assistance for all low-income individuals and families, and lone parents may or may not be treated differently in terms of work-related requirements than other claimants. A number of countries - Australia, France, Ireland, New Zealand, Norway, the United Kingdom and the United States - have special forms of income support for lone parents. Classification as a lone parent depends primarily upon the age of the youngest child. For example, in the United Kingdom when the youngest dependent child turns 16 the (former) lone parent can apply for other forms of income support (with work requirements, unless qualified for other benefits on grounds of disability, age, etc.).

1. All social assistance beneficiaries, including single mothers, are in principle required to be looking for work and to be ready to take up employment. However, in the case of single parents, especially those with young children, this requirement is not enforced very strongly.

2. Required to attend planning meetings and preparing a Personal Development and Employment Plan that covers goals for the future and steps to reach those goals.

3. Required to attend a Work-Focused Interview with a Personal Adviser on application for Income Support and at intervals during receipt of it. From October 2008, lone parents with children aged 12 or over will be required to claim Jobseeker's Allowance (JSA) rather than Income Support, and will therefore be subject to job-search requirements.

4. Until 2006, parenting payment recipients with a youngest child aged less than 6 years had no participation requirement; those with a youngest child aged 6 to 12 years were required to attend an annual Personal Adviser interview; those with a youngest child aged 13-15 years had to undertake 150 hours of approved activities each 26 weeks. From 30 June 2006, single parents still receiving the 
parenting payment recipients when their youngest child turns seven must seek at least part-time work; lone parents with children aged 8 and more making a new benefit application will instead qualify for unemployment benefit (Newstart) with a similar work requirement. There are some exemptions for large families and parents with a child with a disability (Media Release 'Providing Parents With The Support And Assistance They Need To Work', 8 November 2005, http://mediacentre.dewr.gov.au/mediacentre; "Changes to Parenting Payment from 1 July 2006", www.centrelink.gov.au/internet/internet.nsf/services/welfare parents.htm).

5. Social case workers' discretion is the most important aspects in the Japanese social assistance system. There is no special treatment for lone parents, and in 1993 only one-sixth of working-age recipients of social assistance were lone parents (Eardley, T., J. Bradshaw, J. Ditch, I. Gough, and P. Whiteford (1996), Social Assistance in OECD Countries: Country Reports, Department of Social Security Research Report No. 47, London: HMSO).

6. Participation requirements are as follows: Alberta from 6 months; British Columbia from 3 years; Saskatchewan 2 years; Manitoba 6 years; New Brunswick, Prince Edward Island, Nova Scotia and Yukon, no formal requirements; Ontario, school age; Quebec 5 years; Newfoundland and Labrador 2 years; Northwest Territories and Nunavut under 3 years, or under 6 years if 2 or more children.

7. Under national guidelines until 2004, municipalities did not require availability for work when the youngest child was aged less than 5. Since 2004 , municipalities are free to determine work-availability requirements and some now require all lone parents to be available for work depending on individual circumstances.

8. A few states have no exemption from work requirements for adult recipients who are caring for a young child, but 44 have some exemption. About half of these (23) exempt adult recipients with children up to age one; another 16 set the child age limit below one year and five set it higher. In addition, 19 states exempt parents who lack child care, 13 of them limiting this provision to cases where the child is aged six or younger (summary of the situation in 2005, based on www.spdp.org/tanf/work/worksumm.htm).

Sources: as cited, and adapted from OECD (2007), Babies and Bosses - Reconciling Work and Family Life in OECD Countries (Volume 5), Paris.

\subsection{What works? Benefit dependency, employment, poverty}

Several OECD countries have introduced active labour market programmes for welfare benefit clients and tightened requirements to co-operate with work-oriented re-integration measures. Experience with this type of measures is however much more extensive in the case of first-tier out-of-work benefits. As a result, most of the available evidence on "what works" relates to unemployment benefits (Heckman et al., 1999; Martin and Grubb, 2001; OECD, 2005; Carcillo and Grubb, 2006; Kluve, 2006). Broadly, the key messages from this literature are as follows: ${ }^{20}$

- Job-search assistance and job-search requirements: Most empirical studies indicate that jobsearch assistance and counselling have positive employment effects at relatively low cost, especially when combined with job-search requirements that are backed up with moderate benefit sanctions. These measures work best for individuals with relatively good labour market prospects. There remain, however, some doubts on the effects on job quality, as measured in terms of earnings and job duration.

- Training: Training and education programmes typically represent the most sizable component of total expenditures on activation measures. Evidence, as well as theory, suggests opposing effects during and after the training programmes. During participation, less time is available for jobsearch which can reduce search-intensity and job-finding rates (the lock-in effect mentioned before). Once training is completed, employment outcomes are however mainly positive, and mostly outweigh short-run losses. Outcomes differ significantly between groups, however, with larger employment gains found for adult women and little impact for prime-aged men. Individuals with relatively good labour market prospects appear to benefit significantly, whereas the negative lock-in effect is found to dominate for young jobseekers. The effectiveness of human-capital development measures also vary by type of programme, with more positive employment effects of on-the-job training and less favourable results in the case of classroom

20. "Positive" effects here mean that those directly concerned by the measures are doing better. Studies almost never implement a fuller cost-benefit framework that would also account for the costs of implementing the respective programmes or for the consequences of higher off-flow from unemployment for existing workers (substitution or displacement effects). In addition, the majority of studies adopt a short-term perspective and therefore do not capture any longer-term impact of activation measures. 
training. While employment effects of training measures can therefore be positive, the empirical evidence typically shows no or very little impact on hourly wages.

- Work requirements and employment programmes: Private-sector employment programmes can be effective at increasing employment probabilities of participants. In contrast, job-creation schemes in the public sector have been shown to be generally unsuccessful at integrating benefit recipients into the regular labour market. Such programmes might, however, still be justified on other grounds. They can serve as availability tests for individuals who are perceived to lack the motivation for job-search. Also, they might aim at promoting work habits (a form of on-the-job training) and social inclusion of participants, who may already have been out of work for some time. There is, however, little concrete evidence on the merits of public-sector employment programmes in terms of promoting such non-employment outcomes.

These insights provide a useful background when considering the appropriate balance of rights and responsibilities for those relying on minimum-income benefits. However, the nature of their labour market difficulties is likely to be substantially different compared to those receiving unemployment benefits. The above findings, which already indicate some degree of effect heterogeneity, are therefore unlikely to apply equally to these different groups. In addition, most of the above results focus entirely on the effects of activation measures in terms of employment and beneficiary status. While these are clearly important, concerns about the high poverty risks facing those on benefits of last resort suggest that a broader set of outcome measures, including the effects of 'activating' policy measures on the incomes of different groups, is desirable.

i)

\section{Policy packages}

There are only a limited number of comprehensive evaluations of broader welfare-to-work packages targeted at recipients of social assistance and similar benefits. ${ }^{21}$ Although income effects are of crucial importance when considering reforms of income safety-nets, most evaluations do not analyse effects on poverty rates and related indicators but are instead limited to outcomes such as recipient numbers and employment. The well-studied US welfare reform implemented in 1996 is one major exception and it is therefore useful to consider the main evaluation results in some detail. ${ }^{22}$ For a number of reasons, the findings cannot be expected to apply directly in other policy settings (for instance, the US reform was essentially confined to lone parents). They do, however, give some indication of the trade-offs that characterise different policy choices.

A number of studies in the US have paid particular attention to the effect of welfare-to-work measures on the number of recipients of Temporary Assistance for Needy Families (TANF). Recipiency statistics are a very incomplete measure of 'success' as they say nothing about the well-being of individuals who successfully found employment, of those remaining on benefit or of those with neither work nor benefits. But lower benefit dependency does represent a positive outcome if other indicators show no deterioration (and if other benefits do not substitute for the one in question).

21. Even in countries where evaluations of activation measures have focussed on means-tested benefits (e.g., New Start Allowance in Australia; Temporary Assistance for Needy Families in the United States), few or no such studies exist for other benefits which may still be available to those not complying with relevant behavioural requirements (Special Benefit in Australia; Food Stamps in the US).

22. The main element of this reform was replacing the Assistance for Families with Dependent Children with the Temporary Assistance for Needy Families, which is time-limited and subject to more stringent behavioural requirements (in practice, time limits and eligibility conditions, as well as benefit levels, vary enormously across states). Midgley (2008) provides an excellent overview of the academic and political debate leading to this reform. 
In any case, bringing down the number of benefit recipients has been a major objective associated with reforming welfare benefits in a considerable number of US states - and one which has been reinforced by the formula used for allocating federal TANF contributions to states, which rewards 'caseload' reductions. This objective is, for instance, reflected in the use of so-called 'diversion payments' (lump-sum payments on condition that people do not apply for the regular benefit during a specified period), as used in more than half of the states. There are also reports that a range of 'hassle techniques' may be used systematically in order to discourage benefit applications (Midgley, 2008). Terminating benefits and ending participation is in these cases likely to be the principal reason for applying strict benefit sanctions. In other states, sanctions are instead partial and used mainly as a motivational device in order to provide incentives for behaviour that is deemed beneficial or to restore compliance with relevant eligibility conditions. Clearly, the direct impact of such partial sanctions on recipiency numbers will be less strong.

Most US studies suggest that, overall, the number of people receiving TANF (or its predecessor AFDC) declined by 60\% between 1994 and the early 2000s, with about a third of this impact directly attributed to the introduction of 'work-first' measures (Besharov, 2006). However, cuts in spending on a particular benefit do not necessarily translate into lower overall spending. Despite a significant decline in TANF expenditures, per-capita spending on total means-tested support (including the Earned Income Tax Credit, EITC) almost doubled between 1990 and 2004, suggesting that substitution effects might be important and that work-support measures, such as the EITC as well as extended availability of public support for childcare and health insurance, are essential ingredients of packages aiming to reduce reliance on out-of-work benefits (Moffitt, 2008, Figure 1). ${ }^{23}$

There is evidence that earnings and employment of low-income lone parents (the principal target group of the US reform) increased as a result of stepping up welfare-to-work measures. But, unsurprisingly, the more rigorous eligibility requirements, and the resulting narrowing of the group entitled to benefits, meant that average household incomes rose by less or not at all (Cancian et al., 2003). About one third of women leaving TANF were not in employment (at a time when benefit time limits were not yet binding: Acs and Loprest, 2004). In fact, even for those finding employment, the effect on earnings was not much bigger than the loss in benefit incomes. For instance, in his review article, Moffit (2008: p. 24) notes that "if 'making work pay' means ensuring that earnings of a woman are greater off welfare than her welfare benefits on welfare, the evidence does not indicate a very strong effect of that kind, if any." Importantly, several studies have shown that benefit losses were often compensated by higher earnings of household members other than the benefit recipient (Bavier, 2001). A point rarely mentioned in the US debate is that, since TANF is almost exclusively received by lone parents, these 'other' household members could be children or young adults, which can be a cause for concern.

Another set of studies shows that incomes rose and poverty fell but mainly among those who did not enter welfare rather than among leavers (Grogger and Karoly, 2005). This is again indicative of an important role for work-support measures. Because of the way federal funding is allocated to states, some of the positive employment effects can be attributed to a virtuous cycle of declining beneficiary numbers, lower spending on out-of-work benefits, and a resulting increase in funds available for work-related support. ${ }^{24}$ This has facilitated continued employment for working lone parents as well as transitions into

23. Acs and Lopprest (2004) find that Food Stamps were received by up to $70 \%$ of former TANF recipient families and that $20 \%$ of TANF leavers were in receipt of Supplemental Security Income (a disabilityrelated transfer for low-income households).

24. The amount of baseline funding from the federal budget to states is fixed over a number of years (so-called 'block grants') although actual federal contributions depend on a number of 'success' indicators ('caseload', share of benefit recipients in work or employment-related activities). In addition, states have a considerable degree of discretion over how funds are used so reduced spending on basic benefit payments created more room for extending other types of support, notably for childcare. 
work. But since this mechanism is essentially pro-cyclical, and works in the opposite direction during extended downturns, many commentators in the US emphasise the importance of a strong economy for making welfare-to-work measures effective (e.g. Blank, 2003). A second main conclusion emerging from the US experience is that work-first measures are good at increasing employment and reducing benefit dependency, but do little to improve family incomes. Work-support measures, in turn, have a small effect on employment but are effective at boosting incomes and reducing poverty. In combination, these measures strengthen employment and improve the income position of those finding employment. But concerns remain for those who do not.

\section{ii) Individual policy measures}

The US evidence demonstrates that the effectiveness of welfare-to-work policies depends on a large number of factors. It can therefore be difficult to draw conclusions about the effects of individual isolated measures. In fact, because different policy elements interact, evaluations of entire packages are arguably more useful. It is, however, interesting to ask whether individual measures can nevertheless be effective even without being necessarily embedded in a broader reform package and what design features are associated with positive or negative outcomes.

Job-search requirements backed up by moderate sanctions have generally been shown to work well as an instrument to promote transitions from social assistance into work. ${ }^{25}$ Measures to intensify job-search and develop search skills are relatively cost-effective and the 'threat' effects of even small sanctions appear to be sizable. For instance, an evaluation of introducing temporary and partial sanctions (up to 20\%) in the Dutch city of Rotterdam resulted in a doubling of transition rates from welfare to work (van den Berg et al., 2004). There is also evidence that the lock-in effect is of much less relevance for those welfare recipients who are unlikely to succeed at finding a job on their own. In the Rotterdam study, applying sanctions at an earlier stage during the benefit spell was therefore associated with lower long-term unemployment. Mandating participation in time-intensive counselling sessions for social assistance recipients in Aarhus, Denmark, has lead to significant lock-in effects for those who are essentially jobready but not for groups facing more substantial employment barriers (Bolvig et al., 2001, cited in Ochel, 2004). Similar results have been reported for Norway (Roed and Raaum, 2006). However, if introduced without intensive counselling and other job-search assistance, tightening requirements mainly increases employment among individuals with comparatively good labour market prospects. ${ }^{26}$ Moreover, with overly demanding requirements, there is a risk that individuals with weaker job prospects would leave the benefit rolls without work and face much-reduced access to job-search assistance and other employment-related support measures.

Small lock-in effects are also reported for employment programmes and strictly enforced work requirements. A study of a workfare programme recently introduced in Germany, the so-called 'one-euro jobs', finds little negative impact on transition rates into work for participants during the programme (Hohmeyer and Wolff, 2007). Strictly enforced work requirements and participation in employment programmes also do not appear to lead to lower-quality job matches. OECD (2005) reports on empirical studies that suggest 'work first' strategies may have little effect on employment stability and can even improve it. However, the German study suggests that the hoped-for positive longer-term impact of workfare measures on employment probabilities is also very limited (the 'post-programme effect' is insignificant for men and small for women). Findings in other countries are more positive and suggest that work requirements can be especially effective when employment is in the private sector. This has for

25. Voluntary job-search assistance programmes, such as the New Deal for Lone Parents introduced in the UK in the late 1990s, are also effective for those who participate but take-up rates are very low.

26. Findings in a recent study of the introduction of a Job Search Diary in Australia are typical in this respect (Borland and Tseng, 2007). 
instance been shown for the UK New Deal for Young People (Dorsett, 2001). The workfare measures introduced by Danish municipalities as part of the Active Social Policy programme were found to be particularly effective, boosting welfare-to-work transition rates by some 300\% (Bolvig et al., 2003).

One disappointing result of work-first strategies is the frequent lack of discernible positive effects on wage growth (e.g. Card et al., 2001). But compared with work-first strategies, human capital investment approaches are less effective at increasing employment in the short term. It is also not clear that they perform better in terms of job stability or earnings progression and they are expensive to operate. Employment gains are, however, possibly greater in the long term (Bloom and Michaelopoulos, 2001; Hotz et al., 2006). The small number of studies that do follow participants of training and education programmes over a longer period suggest that benefits in terms of employment or earnings take two or more years to emerge (Dyke et al., 2005; OECD, 2005). Whether or not training and education improves labour market prospects depends very much on the circumstances of the benefit recipient. Carcillo and Grubb (2006) cite evidence that less job-ready individuals benefit more from vocational training. Yet this is also the group whose employment probability increases strongly as a result of participation in workfare and employment programmes. On the basis of available evidence, it is therefore difficult to conclude whether a lack of work experience or insufficient skills are the main barrier to employment for social assistance clients.

A number of US studies (such as evaluations of the Portland JOBS programme) found that the most successful programmes employed a mixed strategy combining a strong work focus for job-ready clients and targeted educational and training programmes for those with very low education levels (Blank, 2003). Favourable results of a combination of work-first and qualification programmes are also reported for Norway (Dahl and Lorentzen, 2005). As might be expected, the outcome of comparing employment effects between 'work-first' and 'human-capital' strategies depends strongly on the specific types of measure being compared. For instance, the study of the effects of the UK New Deal for Young People showed that subsidised private-sector employment has a much larger positive impact on employment outcomes than full-time training or education. But the outcomes for those in the training and education programme were no worse when compared with voluntary work or community service (Dorsett, 2001).

\section{Institutional context, programme implementation and service delivery}

A stronger emphasis on labour-market re-integration makes benefits of last resort arguably more similar to unemployment benefits. For countries operating multiple layers of working-age benefits, the question then arises as to what extent employment-related services, such as job-search assistance, should be integrated or kept separate for recipients of the different benefits. An obvious advantage of integration is the economies of scale that can be reaped. Related to that, social assistance beneficiaries can benefit from the expertise and established contacts with employers at the main PES. At the same time, a lack of coordination between the various bodies may result in duplication of effort. Also, PES staff may lack the expertise for assisting clients with severe employability issues. Specialised service providers may in these cases be in a better position to address specific employment barriers and to determine whether job-search activities should be suspended or accompanied by complementary reintegration measures.

Of course, without additional resources for the PES, broadening the client group represents additional demands on PES staff. A diversion of resources from more employable to less employable clients can reduce the overall 'success rate', as proxied, for example, by the population of successful placements into jobs (Carcillo and Grubb, 2006). Yet, if the PES records a number of vacancies for low-skilled workers which they are unable to fill, then drawing on a larger and more diverse pool of job-seekers could also be an advantage. Treating social assistance beneficiaries in a similar way to other unemployed individuals could also increase their motivation levels and reduce stigmatisation by potential employers. 
There is a trend in many OECD countries to provide 'one-stop shops' or service centres for benefit recipients and job seekers. The main attraction from a user's point of view is that services are more easily accessible and information about them can be readily obtained when provided in one place. In addition, having all clients enter through a single 'gateway' facilitates targeting of services and interventions to suit the client's needs and circumstances and can help to break down barriers between the different institutions (e.g. by harmonising terminology). Due to the heterogeneity of the circumstances and needs of social assistance beneficiaries, the case for one-stop shops providing or arranging a broad range of different services and programmes is arguably particularly strong for this group.

Yet, the provision of different services under one roof does not automatically lead to a better coordination of processes and institutional objectives. With the involvement of different institutions (e.g. municipality, PES, social insurance institution), there is considerable scope for diverging objectives and misaligned incentives, regardless of the physical arrangement of the premises. For instance, municipalities financing social assistance expenditures may have an incentive to shift budgetary responsibility for a client to other programmes while the PES may have little interest in adding hard-to-place individuals to their client base. ${ }^{27}$ One result can be an expensive, but ineffective, 'cycling' of clients through labour market programmes. If these issues are not addressed (e.g. by using more finely-grained output targets such as setting separate performance objectives for each group of PES clients), then the different parts may largely operate side-by-side without the synergies of a joint or fully co-ordinated operation.

To improve coherence between different labour market programmes and support measures, some countries have created a separate institution charged with co-ordinating the delivery of programmes (the US Workforces Investment Boards are one example). Several other OECD countries, including Austria, Finland, France and Germany, operate multiple benefits in an often complex institutional context and have recently sought to improve co-ordination between the different bodies. Emerging evaluations of these institutional innovations (in Finland and Germany) will potentially provide valuable insights into the strengths and weaknesses of different approaches.

The degree of decentralisation of benefit administration and service delivery is partly historically determined and sometimes subject to rigid legal constraints. It can, however, also present a tool to make support packages more adaptable to local labour markets and the reasons for clients' employment difficulties. Many countries have recently decentralised various aspects of labour market policy (OECD, 2003b). Essentially, decentralisation can be a strategy to improve the targeting of benefits and the rights and responsibilities attached to them. Decentralised service delivery can also be better tailored to local labour markets and policies. Compared with a highly centralised administrative structure, regional or local institutions are likely to be in a better position to build valuable links with local actors such as employers, community groups or support networks. By delegating both budgetary and operational responsibilities to the regional or local level, it is in principle possible to strengthen institutional incentives, resulting in a better correspondence between budgetary expenditures, the choice and duration of re-integration services offered and the success at reducing benefit dependency.

Delivery of social assistance-related services is highly decentralised in most countries. In federally organised countries, political responsibility (i.e. the formulation of legal rules or guidelines) tends to lie with regions or municipalities as well. However, as noted, a stronger welfare-to-work focus can lead to

27. For instance, the introduction of mandatory community work for social-assistance recipients in Belgium in the late 1980s led to a sizable reduction of exit rates from unemployment to work. One likely reason is that participation in the work programme allowed individuals to re-qualify for unemployment benefits. The welfare agency therefore had incentives to assign benefit recipients to temporary community work in order to shift the budgetary burden of benefit payments to the unemployment insurance institution (Cockx and Ridder, 2001). 
closer links with the PES which operates in a centrally-determined policy framework and funding context in practically all OECD countries. It is important to recognise that different institutions and levels of government are likely to differ in their objectives or priorities (e.g. local development versus minimising labour-market inactivity rates in the country as a whole). As a result, a new institutional balance may implicitly alter output targets even if this is not an explicit objective of institutional changes.

The argument for decentralisation is that it should encourage innovations in policies and lead to greater dissemination of good practices. But in reality it is often hard to (a) get decentralised administrations to invest in the necessary data collection and rigorous evaluations, and (b) to have relevant evaluation results readily shared with other jurisdictions.

While the point of decentralisation is to encourage diversity of approaches, there can also be concerns if variations in the type and availability of financial or non-financial support become very large. For instance, some US commentators are concerned on equality grounds about large differences in benefit levels, behavioural requirements and strictness of sanctions across US states. Although the variation of social assistance policies operated by the nine states (Länder) in Austria is not as large as in the US, the Austrian federal and state governments have, for related reasons, started to work towards an agreement to unify payment rates and some eligibility rules. Equity concerns can also arise if decisions about client obligations and benefit eligibility are largely made on the basis of caseworker discretion. When faced with complex information and a lack of formal rules, stereotyping is one possible strategy caseworkers might employ in reaching entitlement decisions and assigning clients to services or programmes. This is more likely if the resource situation at the benefit office is such that it does not permit a comprehensive evaluation of clients' circumstances, work capacity and needs.

A fragmented institutional context, with many different actors and complex accountability lines, is likely to exacerbate problems of perceived inequality of service availability and quality. For instance, outsourcing service delivery to non-governmental providers, with their own profit or non-profit motives, requires the introduction and administration of entirely new quality control systems, both to secure quality standards and to limit the scope for unintended "creaming" or other potentially harmful profit maximisation strategies. Ensuring comparable performance and service standards is a particular challenge in such decentralised systems of service delivery. Many OECD countries have a long history of outsourcing training and job-creation programmes. A few countries have also started contracting placement services to external providers and some are outsourcing a broad range of re-integration services (notably Australia and the Netherlands: see OECD, 2003; Tergeist and Grubb, 2006). The United States also has had considerable experience with contracting a range of social services to non-governmental commercial and non-profit providers, including religious (or "faith-based") organisations. Many of these organisations are highly respected providers of social services. There has however been a long-running debate in the US about the role of religious organisations who, since the "welfare reform" legislation came into effect in 1996, are no longer required to strictly separate their social service and sectarian activities (see e.g., Midgley, 2008). 


\section{Concluding comments: current and future challenges}

The current economic downturn is putting pressures on governments to strengthen income support measures (OECD, 2009b). While buoyant labour markets in many OECD countries have helped to restrain recipiency numbers since the mid-late nineties, the current rapid decline in economic activity can be expected to be a powerful driver of the demand for minimum safety-nets.

In addition to the expected lengthening of average unemployment spells, and the resulting rising number of people running out of unemployment benefit entitlements, those with temporary jobs or other forms of non-standard employment are often not entitled to unemployment benefits in the first place. For these individuals, employment durations are shorter, transitions into and out of work more frequent and coverage by social insurance benefits can be less universal as a result. They are also typically more easily shed from the workforce. With increasing shares of non-standard workers in a number of OECD countries $^{28}$, this may cause social assistance benefit rolls to react more strongly to labour-market conditions (i.e., become more counter-cyclical) than was the case in the past. In the medium term, some of these challenges point to the need for a debate on the relative roles of insurance and assistance benefits. For instance, should coverage of insurance benefits be extended to non-standard workers or should lower-tier assistance benefits be strengthened?

More urgently, there is a need to consider how an activation and reintegration focus can be maintained when labour demand is weak and competition for existing job vacancies intense (OECD, 2009b, c). Where minimum-income programmes are lower-tier benefits, recipients tend to face significantly less promising employment prospects in a slack labour market than recipients of unemployment benefits with more recent work experience. Yet, the group of minimum-income beneficiaries is very heterogeneous in most countries including, for instance, those with recent but intermittent employment records and other recent job losers who do not qualify for insurance benefits. Increasing numbers of benefit recipients are likely to test the capacity of welfare agencies and public employment services to administer high-quality activation programmes and job-search assistance to everybody. This will further add to the challenge of targeting activation and support measures in a way that minimises benefit spells for the most employable, while preventing less employable clients from becoming permanently benefit-dependent.

The most immediate priority, however, is to prevent support seekers from going without effective minimum safety-nets at a time when they are most needed. Preventing steep increases in the extent and severity of poverty is likely to present a particularly difficult short-term challenge for those countries that are not currently operating broad minimum-income programmes. In addition, existing social assistance programmes are likely to see new clients added at much faster rates as unemployment durations lengthen. They will only be able to continue meeting their objectives of poverty alleviation and activation if they are equipped with the financial and operational capacity to deal with the inflow of new claimants and an increasing stock of recipients.

28. Although trends are far from uniform across OECD countries, the share of temporary employment in EU-15 countries has increased by about 20\% during the past decade (to $14.8 \%$ in 2007). Temporary work accounts for more than $20 \%$ of total employment in Poland and Portugal, while almost every third employment contract in Spain is non-permanent. Outside of Europe, Japan has seen a particularly strong expansion of non-standard forms of employment. 


\section{REFERENCES}

Adema W., D. Gray and S. Kahl (2003), “Social Assistance in Germany“, Labour Market and Social Policy Occasional Papers, No. 58, OECD, Paris.

Acs, G. and P. Loprest (2004), Leaving Welfare, Upjohn Institute, Kalamazoo, MI.

Bargain, O., H. Immervoll and H. Viitamäki (2009), “No Claim, No Pain. Measuring the Non-Take-up of Social Assistance using Register Data”, unpublished manuscript.

Van den Berg, G., B. van der Klaauw and J. van Ours (2004), "Punitive Sanctions and the Transition Rate from Welfare to Work”, Journal of Labor Economics, Vol. 22 (1), pp. 211-41.

Besharov, D. (2006), Two Cheers for Welfare Reform, American Enterprise Institute, Washington D.C.

Blank, R.M. (2003), “U.S. Welfare Reform: What’s relevant for Europe?”, CESifo Economic Studies, 49 (1), 49-74.

Blank, R.M. (2007), “Improving the Safety Net for Single Mothers who Face Serious Barriers to Work”, The Future of Children, Vol. 17(2), pp. 183-97.

Bloom, D. and C. Michalopoulos (2001), “How Welfare and Work Policies Affect Employment and Income: A synthesis of Research”, Manpower Demonstration Research Corporation, New York.

Boon, J. and J. C. van Ours (2009), "Why Is There a Spike in the Job Finding Rate at Benefit Exhaustion?”, IZA Discussion Paper No. 4523, Institute for the Study of Labor, Bonn.

Borland, J. and Y.P. Tseng (2007), "Does a Minimum Job Search Requirement reduce Time on Unemployment Payments? Evidence from the Job Seeker Diary in Australia”, Industrial and Labour Relations Review.

Bolvig, I., P. Jensen and M. Rosholm (2003), “The Employment Effects of Active Social Policy”, IZA Discussion Paper No. 736, Institute for the Study of Labor, Bonn.

Bolvig, I., P. Jensen and M. Rosholm (2001), Effekter af aktiveringsindsatsen i Århus Kommune, Aarhus.

Cancian, M., R. Haveman, D. R. Meyer and B. Wolfe (2003), “The Employment, Earnings, and Income of Single Mothers in Wisconsin Who Left Cash Assistance: Comparisons among Three Cohorts”, Institute for Research on Poverty, Special Report No. 85, Madison.

Cappellari, L. and S.P. Jenkins (2008), “The Dynamics of Social Assistance Receipt: Measurement and Modelling Issues with an Application to Britain”, OECD Social, Employment and Migration Working Papers, No. 67, OECD, Paris. www.oecd.org/els/workingpapers. 
Carcillo, S. and D. Grubb (2006), "From Inactivity to Work: The Role of Active Labour Market Policies”, OECD Social, Employment and Migration Working Papers, No. 36, OECD, Paris. www.oecd.org/els/workingpapers.

Card, D. E., R. Chetty and A. Weber (2007), “The Spike at Benefit Exhaustion: Leaving the Unemployment System or Starting a New Job?” American Economic Review, Vol. 97, 113-18.

Card, D.E. and P.B. Levine (2000) Extended Benefits and the Duration of UI Spells: Evidence from the New Jersey Extended Benet Program”, Journal of Public Economics, Vol. 78, 107-38.

Card, D., C. Michalopoulos and P. Robins (2001), “The Limits to Wage Growth: Measuring the Growth Rate of Wages for Recent Welfare Leavers”, NBER Working Paper No. 8444, National Bureau of Economic Research, Cambridge, MA.

Dahl, E. and T. Lorentzen (2005), "What Works for Whom? An Analysis of Active Labour Market Programmes in Norway”, International Journal of Social Welfare, Vol. 14 (2), pp. 86-98.

Dyke, A., C.J. Heinrich, P.R. Mueser and K.R. Troske (2005), “The Effects of Welfare-to-Work Program Activities on Labor Market Outcomes”, IZA Discussion Paper No. 1520, Institute for the Study of Labor, Bonn.

Eardley, T, J. Bradshaw, J. Ditch, I. Gough, and P. Whiteford (1996), Social Assistance in OECD Countries: Synthesis Report, OECD, Paris and Department of Social Security, Her Majesty's Stationary Office, London.

Grubb, D., S. Singh and P. Tergeist (2009), “Activation Policies in Ireland”, OECD Social Employment and Migration Working Paper No. 75, OECD, Paris. www.oecd.org/els/workingpapers.

Heckman, J.J., R.J. LaLonde and J.A. Smith (1999), “The Economics and Econometrics of Active Labor Market Programs”, in: O. Ashenfelter and D. Card (eds.) Handbook of Labor Economics, Elsevier.

Hernanz, V., F. Malherbet and M. Pellizzari (2004), "Take-up of Welfare Benefits in OECD Countries: A Review of the Evidence”, OECD Social Employment and Migration Working Paper No. 17, OECD, Paris. www.oecd.org/els/workingpapers.

Hohmeyer, K. and J. Wolff (2007), “A Fistful of Euros: does one-euro-job participation lead means-tested benefit recipients into regular jobs and out of unemployment benefit II receipt?“, IAB Discussion Paper No. 3207, Institute for Employment Research, Nuremberg.

Hotz, V.J., G. Imbens and J. Klerman (2006), “Evaluating the Differential Effects of Alternative Welfareto-Work Training Components: A reanalysis of the California GAIN program”, Journal of Labor Economics, Vol. 24, pp. 521-66.

Immervoll, H., H.J. Kleven, C.T. Kreiner and E. Saez (2007), "Welfare Reform in European Countries: A Micro-simulation Analysis”, Economic Journal, Vol. 117 (517), pp. 1-44.

Immervoll, H. and M. Pearson (2009), “A Good time for Making Work Pay? Taking stock of in-work benefits and related measures across the OECD”, OECD Social, Employment and Migration Working Paper No. 81 and IZA Policy Paper No. 3. www.iza.org/en/webcontent/publications/policypapers. 
Kalužná, D. (2008a), "Main Features of the Public Employment Service in the Slovak Republic”, OECD Social, Employment and Migration Working Paper, No. 72, Paris. www.oecd.org/els/workingpapers.

Kalužná, D. (2008b), “Main Features of the Public Employment Service in the Czech Republic”, OECD Social, Employment and Migration Working Paper, No. 74, Paris. www.oecd.org/els/workingpapers.

Kalužná, D. (2009), "Main Features of the Public Employment Service in Poland”, OECD Social, Employment and Migration Working Paper, No. 80, Paris. www.oecd.org/els/workingpapers.

Katz, L. F. and B. D. Meyer (1990), “The Impact of the Potential Duration of Unemployment Benefits on the Duration of Unemployment”, Journal of Public Economics, Vol. 41, 45-72.

Kluve, J. (2006), “The Effectiveness of European Active Labor Market Policy”, IZA Discussion Paper No. 2018, Institute for the Study of Labor, Bonn.

Lalive, R., J. C. van Ours and J. Zweimüller (2006), "How Changes in Financial Incentives Affect the Duration of Unemployment”, Review of Economic Studies, Vol. 73, 1009-38.

Martin, J.P. and D. Grubb (2001), "What Works and for Whom: A Review of OECD Countries' Experiences with Active Labour Market Policies”, IFAU Working Paper No. 2001:14, Office of Labour Market Policy Evaluation (IFAU).

Midgley, J. (2008), "Welfare Reform in the United States: Implications for British Social Policy (with Commentaries by Kitty Stewart, David Piachaud and Howard Glennerster)”. LSE STICERD Research Paper No. CASE131, London.

Ochel, W. (2004), "Welfrae-to-Work Experiences with Specific Work-first programmes in selected Countries”, CESifo Working Paper No. 1153, CESifo, Munich.

OECD (1998a), The Battle against Exclusion, Social Assistance in Australia, Finland, Sweden and the United Kingdom, Vol. 1, OECD, Paris.

OECD (1998b), The Battle against Exclusion, Social Assistance in Belgium, the Czech Republic, the Netherlands and Norway, Vol. 2, OECD, Paris.

OECD (1999), The Battle against Exclusion, Social Assistance in Canada and Switzerland, Vol. 3, OECD, Paris.

OECD (2005), Employment Outlook, OECD, Paris.

OECD (2003a), “Benefits and Employment, Friend or Foe? Interactions Between Passive and Active Social Programmes”, Employment Outlook. OECD, Paris.

OECD (2003b), Managing Decentralisation. A New Role for Labour Market Policy, OECD, Paris.

OECD (2005), Employment Outlook, OECD, Paris.

OECD (2007a), “Special Feature: The Tax Treatment of Minimum Wages”, in: Taxing Wages. Paris, pp. 22-34.

OECD (2007b), “Can Parents Afford To Work? Childcare Costs, Tax-Benefit Policies and Work Incentives”, in: Benefits and Wages. OECD Indicators. Paris, pp. 119-166. 
OECD (2008), Growing Unequal? Income Distribution and Poverty in OECD Countries. Paris.

OECD (2009a), “Incomes and Poverty of Older People”, in: Pensions at a Glance. Retirement-income Systems in OECD Countries. Paris, pp. 55-84.

OECD (2009b), “The Jobs Crisis: What are the Implications for Employment and Social Policy?”, in: OECD Employment Outlook: Tackling the Jobs Crisis. Paris, pp. 17-116.

OECD (2009c), “Maintaining the Activation Stance during the Crisis”, Background paper for the Meeting of the Employment, Labour and Social Affairs Committee at Ministerial Level, DELSA/ELSA/MIN(2009)4.

Roed, K. and O. Raaum (2006), “Do Labour Market Programmes speed up the Return to Work?”, Oxford Bulletin of Economics and Statistics, Vol. 68 (5), pp. 541-68.

Roed, K. and T. Zhang (2003), “Does Unemployment Compensation Affect Unemployment Duration?”, Economic Journal, Vol. 113, 190-206.

Tergeist, P. and D. Grubb (2006), “Activation Strategies and the Performance of Employment Services in Germany, the Netherlands and the United Kingdom”, OECD Social, Employment and Migration Working Paper, No. 42, Paris. www.oecd.org/els/workingpapers.

STAKES (2008), “Social Assistance 2007”, Statistical Summary 37/2008. 